\title{
Aoristo)))))
}

International Journal of Phenomenology, Hermeneutics and Metaphysics

\section{Sobre abrírfendas, cravar o chão da exístêncía: verdade e liberdade no pensamento tardio de Heidegger}

\author{
About opening cracks, digging into the ground of existence: \\ truth and freedom in Heidegger's afterthought
}

\author{
Prof. Dr. Daniel Rodrigues Ramos \\ Universidade Federal do Recôncavo da Bahía - UFRB'
}

\section{RESUMO}

Discute-se a questão da liberdade humana a partir da sua essencial vinculação com a questão da verdade, conforme a indicação da conferência Wom Wesen der Wahrheit (1930), mostrando a interpendência das questões a partir dos desdobramentos tardios da reviravolta (Kehre) do pensamento heideggeriano. Nesta direção, tenta-se reconduzir progressivamente a essência da verdade, definida como o deixar-ser (Sein-Iassen) da liberdade existencial, para o acontecimento do ser enquanto a originária liberação da clareira para auto-ocultação, recolocando nela o fenômeno da liberdade. Neste movimento, procura-se mostrar como a abertura ek-sistencial com sua liberdade funda-se no livre da clareira. Contudo, esta vigora no modo de um fundamento abissal que o ser humano experimenta como um fosso ou ferida no centro da própria existência. Demonstra-se, então, que o essencial da questão da liberdade humana é assentar a existência no chão ou fundo fendido pela vigência misteriosa e abissal do ser. Para tanto, parte-se da identificação do âmbito originário de elaboração da questão da liberdade até remetê-la, passo a passo, à experiência do fissuramento da existência. Este caminho desdobra o eixo condutor da meditação, cuja formulação é inspirada na conferência acima nomeada: a verdade da liberdade é a liberdade da verdade.

\section{PALAVRAS-CHAVE}

A questão do ser; verdade; liberdade; fundamento; Da-sein

\section{ABSTRACT}

\footnotetext{
${ }^{1}$ E-mail: dr.ramos@outlook.com.br. Orcid: https://orcid.org/0000-0001-6059-4400
}

\author{
Daniel Rodrigues Ramos \\ Toledo, v. 4, n・1 (2021) p. 105 141
}




\section{Aoristo)))))}

International Journal of Phenomenology, Hermeneutics and Metaphysics

The question of human freedom is discussed from its essential link with the question of truth, as indicated by the conference Wom Wesen der Wahrheit (1930), showing interdependence of the questions from the late unfolding of the heideggerian thoughts reversal (Kehre). In this direction, an attempt is made to progressively re-conduct the essence of truth, defined as the letting-being (Seinlassen) of existential freedom, to the event of being as the original liberation of the clearing for selfsheltering-concealing, placing in it the phenomenon of freedom. In this movement, an attempt is made to show how the ek-sistential openness with its freedom is founded on the freedom of the clearing. However, it is in the form of an abyssal ground that human being experiences a wound or cleft at the center of his own existence. It becomes clear, then, that the essential aspect of the question of human freedom is to settle existence on the ground or in the depths divided by the mysterious and abyssal swaying of being. To this end, one begins by identifying the original scope of the elaboration of the question of freedom by referring it, step by step, to the experience of the cleavage of existence. This path unfolds the guiding axis of meditation, whose formulation is inspired by the conference mentioned above: the truth of freedom is the freedom of truth.

\section{KEY-WORS}

The question of being; truth; freedom; ground; Da-sein

\section{INTRODUÇÃO}

A harmonia invisível é mais forte que a visível. Caminho: para cima, para baixo, um e o mesmo. (Heráclito de Éfeso, fragmentos 55 e 60)

Ser homem significa encontrar-se na possibilidade do estranho mais extremo - porém, ao mesmo tempo, também na possibilidade da mais próxima e levíssima dissipação no fugaz, palpável, acionável. (Heidegger, Zum Ereignis-Denken)

O título da presente meditação indica onde se aspira chegar, a saber, descrever a experiência humana da liberdade, em sua mais radical verdade, a partir da concretização da existência história e finita do ser humano. Há pouco mais de um século, percebe-se de modo mais agudo que esta experiência do destino da humanidade se faz sem chão seguro. Impera o pressentimento de um perigo e a expectativa do inusitado, já que "o horizonte nos aparece novamente livre, embora não esteja limpo", como nos adverte Nietzsche (2001, p. 234) ao pensar o sentido da jovialidade de nossa existência no tempo atual de uma grande derrocada do Ocidente e de finalização da tradição que ainda hoje nos entrega o seu passado. Porém, o passado se fechou na sua originária significância, não mais orienta para o futuro e parece ser novamente acessível unicamente por uma perspicaz e profunda destruição da história. Vemo-nos, então, em becos sem saída, existencialmente

Sobre abrirfendas, cravar o chão da existêncía: verdade e liberdade no pensamento tardio de Heidegger 


\title{
Aoristo)))))
}

International Journal of Phenomenology, Hermeneutics and Metaphysics

situados em aporias. Assim, pressente-se em toda parte, em todas as instituições e situações em que se depositam os desdobramentos do mundo ocidental em sua história, que toda solidez do passado e da tradição se converteu na fluidez dos ares da modernidade. Neste sentido, aquela experiência de constituição do ser humano, enquanto liberdade para ser e concretizar a sua essência, dado que já não se sabe mais com tanta segurança quem somos nós com as nossas próprias circunstâncias, que se liberam nesta livre concretização histórica de nosso ser, é o confronto com a inalienável indigência, de um profundo desenraizamento da existência. Nesta situação, se estamos às portas de outra inauguração da histórica, da liberação do homem com seu mundo para outro modo de existir e coexistir, sente-se que a liberdade deve ser apreendida desde a condição que se encontra a humanidade imersa na evasão de um chão que escorre como se fosse água.

Deste modo, está fissurada e ferida a nossa existência - e isto, desde o seu cerne! Encontra-se socavada em margens tênues que, porém, encobrem imensa profundidade. Dizendo com Heidegger, ferida por uma fenda que é o profundo abismo de uma não dimensionada ausência, pois mal pressentida e ainda não pensada a fundo e, por isso, não reverberou como transformação da essência do existir do homem. Pairamos oscilantes no ar e, no entanto, asfixiados por um vazio, sem amplo espaço para a expansão de nossa existência. Por outro lado, vale para esta situação histórico-existencial de "um vazio aprisionado nos braços para os espaços que respiramos", a analogia profética do poeta: "Talvez os pássaros sintam, num vôo de maior intimidade, o ar mais amplo". (RILKE, 2005, p. 135) A expansão para o mais amplo de nossa existência então está ligada com a radicalidade da prontidão e disposição corajosas para medir-se com esta ausência, senti-la em seu íntimo, dimensionando-a. Então, para nós, isto é, na perspectiva do discurso da experiência que se traduz essencialmente apenas no lógos do existir, esta é a questão da liberdade e da verdade: poderá a fenda que se crava no seio de nossa existência se anunciar como impulso e ardor para o (outro) levante do ser do homem, porém, desde uma transformação não dantes vista de sua essência? Poderá o tempo das indigências mais profundas e subtis ser um kairós? Chegaríamos a perceber que o vazio que nos angustia não é dado tão somente da não ocorrência de sentido, que nada tem a ver com não preenchimento do espaço exterior ou de uma interioridade subjetivaespacializada, mas sim com o misterioso modo do ser se dar inesgotavelmente, a plenitude do mais simples a se ocultar em todas as coisas? Por conseguinte, a errância do existir humano nos tempos atuais é o apelo a um decisivo exercício da liberdade, para uma grave decisão a respeito do destino histórico da humanidade: se permanecemos enrijecidos no ressentimento de um niilismo negativo, reativo, ou se seremos aptos para abrir nossa existência, apreendendo nossa verdade desde um sereno sabor da ausência, do nada do ser, em outro levante da existência humana sobre esta terra. Por certo, nossa resposta muito dependerá da nossa intimidade com o sentido deste acontecimento do fendilhamento de nossa existência - é o que

\author{
Daniel Rodrigues Ramos \\ Toledo, v. 4, n'1 (2021) p. 105 141
}




\section{Aoristo)))))}

International Journal of Phenomenology, Hermeneutics and Metaphysics

queremos mostrar a partir de breves reflexões sobre a verdade e a liberdade no pensamento tardio de Heidegger.

Este levante define a essência do homem, (HEIDEGGER, 2013, p. 32) define a questão essencial do homem em ter que se constituir, em ter que liberar-se ao extasiar sua ek-sistência: ultrapassar-se, saltar-se abrindo-se desde o (pro)fundo originário de seu ser. Ora, na noite escura do tempo presente, este surgir em si mesmo, livremente e libertadoramente, só é possível se assentado no chão ausente ou um fundamento que, ao se retrair, fende a existência humana. Pois este levante é o mais oculto, enigmático e, embora o ponha em obra a todo o instante, desta sua essência o homem dele se esquece. Contudo, não se oculta por demérito humano, mas sim por graças do ser mesmo, pois este levante apenas vigora na decisão livre de deixar-se pertencer no cuidado e no abrigo do mistério do ser. Deste modo, o levante, pelo qual o homem surge em si e para si mesmo, já é a resposta ao velamento da verdade que o estremece em sua existência, convoca e o atrai até tomá-lo inteiramente. Só assim a recusa da ausência fende a existência humana e neste fosso abissal a liberdade deve cravá-la, dando-lhe chão. Então, surgimos no levante que somos, se penetramos na intimidade desta fenda, no abscôndito do acontecimento da verdade, salvaguardando o mistério do ser que esta originária fissuração protege. No centro deste levante cravado no chão profundamente fissurado está o acontecimento de acolhida do homem de sua essência ainda desconhecida, de apropriação de sua verdade e, ao mesmo tempo, "a essência mais profunda da história". (HEIDEGGER, 2003c, p. 311; tr. por. p. 303)

Por tudo isto acima dito, mesmo que ainda de maneira muito provisória e com notória vagueza, o título poderia ter sido inspirado na condição sociopolítica e, sobretudo, existencial do camponês brasileiro, expulso de sua terra e expropriado do chão de sua subsistência e de suas experiências mais fundamentais para a maturação de sua identidade, cantada nestes versos do cancioneiro brasileiro: "Como então? Desgarrados da terra? Como assim? Levantados do chão? Como embaixo dos pés uma terra como água escorrendo da mão?". (BUARQUE; NASCIMENTO, 1997) Contudo, tenho diante de meus olhos um escrito de folhas cravadas esmeradamente com os timbres de uma antiga máquina de escrever, amareladas pelo tempo. São estas folhas a central inspiração da meditação que aqui se intenta, as quais testemunham um profundo esforço de pensar, de ver e fazer ver o fenômeno na concretude de seu patentear-se. Trata-se de um material didático, no excelente significado deste adjetivo, cuidadosamente elaborado com a marca do caráter apofântico que exige todo bom discurso fenomenológico. Aliás, é um discurso concebido para conduzir o seminário, ocorrido em 1970, em torno da conferência Vom Wesen der Wahrheit (1930), de Heidegger. Contém não só ricas reflexões ou exercícios de um pensar autenticamente fenomenológico que tentam abrir brechas no texto da conferência, mas também ricas indicações de como se medir com postura filosófica e com grandeza humana no estudo do texto escolhido para o seminário e na aprendizagem do pensar. No seu tom pedagógico, ensina aos participantes do seminário, já nas páginas iniciais, nas palavras do autor, a "abrir uma fenda no texto"

Sobre abrirfendas, cravar o chão da existêncía: verdade e liberdade no pensamento tardio de Heidegger 


\section{Aoristo)))))}

International Journal of Phenomenology, Hermeneutics and Metaphysics

por meio de uma incansável "luta livre com o texto". (HARADA, 1970, p. 6) Ensina, sobretudo, a fazer o mesmo com a própria existência. E ressaltando esta postura, que se observa ao longo das páginas - e, certamente, na vida e obra do seu autor - que as últimas linhas deste escrito o concluem:

Essa rachadura [da ausência, silêncio, esquecimento, velamento do ser] que liberta o campo aberto onde se coloca a questão da essência da verdade, onde se percebe a diferença onto-lógica entre o mistério do ser e o seu esquecimento, entre ser e ente, é a ferida originária que nasce juntamente com o desvelamento do ser. Desta ferida (Ursprung, salto originário) irrompe o abismo infinitesimal da Wende (versão, guinada), como o movimento da errância, como desgarramento que embala a História da Humanidade na busca trans-cendental dissimulada de sua própria origem como Unidade da total identidade. Esse movimento da trans-cendência que hoje se camufla na expansão imperialista e planetária da civilização científico-tecnológica é a Meta-física, lugar onde habita a questão do ser do ente (...). A Liberdade como ek-sistência in-sistente na presença do desvelamento na ausência dissimulada é filosofia. A essência da Verdade é a essência da filosofia. (HARADA, 1970, p. 56)

O "sangue", a vida que eclode da ferida originária da existência errante do homem é fonte arcaica da liberdade, a qual convida sem exclusão o ser humano, em qualquer tempo e sociedade, desde que se a experimente com decisão, a tornar-se pensador, a fazer do fosso da existência uma dádiva que se acolhe unicamente com a resposta cordial e serena do e para o pensamento enquanto caminho de autoliberação, perfeição e grandeza na tarefa de se tornar humano. Por este ensinamento, a seu autor, frei Hermógenes Harada, a quem esta desajeitada meditação homenageia, minha gratidão.

\section{COLOCANDO A QUESTÃO}

\subsection{A QUESTÃO FUNDAMENTAL E A ESSÊNCIA DA LIBERDADE}

$O$ pensamento de Heidegger pode ser tomado por uma fenomenologia da liberdade. Como ensina este pensador da Floresta Negra, interpretar é compreender algo como algo; é considerar o compreendido nas suas conjunturas ao explicitá-lo desde uma visão prévia, nem sempre claramente explícita. (HEIDEGGER, 2006a, p.149-150) Deste modo, sempre há o risco do pensar metafísico-objetivante ingerir-se nesta estrutura, o que leva de antemão a tomar o primeiro algo como uma efetividade ou propriedade de certa realidade reificada e, na mesma linha, considerar o segundo como a coisa em si, porém, equivalente à determinação comum ou generalidade vazia. Assim acontece com a liberdade ao considerá-la, não como o acontecimento da liberação originária (do ser) de tudo que é, mas sim como o arbítrio ou como qualidade de um ato de um sujeito representador, que para se afirmar como

$$
\begin{array}{r}
\text { Daniel Rodrigues Ramos } \\
\text { Toledo, v. 4, n・1 (2021) p. 105 141 }
\end{array}
$$




\section{Aoristo)))))}

\section{International Journal of Phenomenology, Hermeneutics and Metaphysics}

livre deve fundar seu agir numa causalidade a priori, independente de toda coação externa. Nesta perspectiva hermenêutica, pensa-se a o homem como proprietário da liberdade e, ao mesmo tempo, aprisiona-a a um pensamento fixado nas condições do agir moral e cujo campo de visão é delimitado à dimensão ôntico-antropológica da realização do ser do homem. Contudo, na esteira da desconstrução e superação da metafísica, sempre se colocou a fenomenologia de Heidegger. Assim, com este modo acima de se ter e aproximar-se do pensamento heideggeriano, enquanto fenomenologia da liberdade, é necessário antes visar a tendência inerente e fundamental que serve como guia e sentido a este pensamento. De outro modo, se esta interpretação do pensamento heideggeriano é viável e justificável, justamente na via dos desdobramentos do questionamento de sua questão fundamental, certamente, isto não se dará pelo fato que a liberdade aparecer, explicitamente, como tema e conceito operativo da obra de Heidegger ${ }^{2}$. Por conseguinte, a interpretação demonstrará a sua própria viabilidade se à questão fundamental da obra e do pensamento interpretado admitir, a partir dela mesma, pertencer a liberdade como dimensão inerente, constituinte e necessária, em síntese, como algo originário da causa em questão deste pensamento, do início ao fim.

Tal questão, tantas vezes retomada e reafirmada pelo pensador como sendo a única de seu itinerário filosófico, mas concebida em diferentes modos enquanto um permanecer junto à coisa mesma a ser pensada (zu denkenden Sache), (HEIDEGGER, 2006c, p. 149) é nomeada, em Sein und Zeit, como sendo a questão do sentido do ser. Posteriormente, a partir da denominada viragem (Kehre), é elaborada como a questão da verdade do ser. Deste modo, definindo o itinerário de seu pensamento no caminho de questionamento de uma só questão, a Frage nach dem »Sinn des Seyns «3 Heidegger (2003c, p. 84-85) explicita que esta mudança de perspectiva de questionamento não corresponde a nenhum desenvolvimento gradual, a nenhuma complementação do anterior no posterior, nem à explicitação pelo posterior de algo incluso no pensamento anterior. Decisivo nesta reformulação da questão é a mudança de lugar de posicionamento do questionamento. Porém, este deslocamento do lugar de questionamento também não é uma escolha casual ou arbitrária do pensador. É exigido pela necessidade mesma de questionar cada vez mais originariamente a coisa a ser pensada e, neste sentido, é imposta pela questionado, o ser enquanto oferecimento de uma doação inaugural, isto é, como fonte encoberta do

\footnotetext{
${ }^{2}$ A explícita tematização do conceito comparece somente a partir do fim dos anos 20 e início dos anos 30, em especial, com as conferências Wom Wesen des Grundes (1929) e Vom Wesen der Wahrheit (1930), como bem observa FIGAL (2005, p. 29). A esta lista deve-se acrescentar a preleção, ministrada no semestre de verão de 1930, em Freiburg, intitulada Wom Wesen der menschichen Freiheit. Einleitung in die Philosophie, volume 31 obras completas (GA).

${ }^{3}$ Note-se que a formulação em alemão da questão do sentido do ser vem grafada entre aspas e utiliza-se a grafia antiga para a palavra ser, Seyn, com a qual Heidegger utiliza para indicar uma dimensão originária da verdade e o fundamento abissal de todo e qualquer ente, porém, esquecidos pela metafísica, mas para a qual o seu pensamento se volta a partir da Kehre (cfr. nota 4). Em Sein und Zeit, a sua única questão é nomeada simplesmente como sendo a Frage nach dem Sinn von Sein.
}

Sobre abrir fendas, cravar o chão da existêncía: verdade e liberdade no pensamento tardio de Heidegger 


\section{Aoristo)))))}

International Journal of Phenomenology, Hermeneutics and Metaphysics

ente na totalidade e, como tal, fundamento esquecido de toda a história da metafísica.

Nesta direção, interdita-se a possibilidade de colocar, de um lado, a Seinsfrage, a questão do ser, e, de outro, a Wahrheitsfrage, a questão da verdade, e até mesmo restabelecer a ligação entre as mesmas por uma relação de progressão, causalidade ou complementaridade. A relação possível se impõe somente no âmbito do jogo tenso de unidade e rupturas. Estas últimas, mantêm, paradoxalmente à primeira vista, unitária a identidade deste pensamento, uma vez que foram necessárias para ir abissalmente a

fundo na mesma questão e, assim, consumar a tarefa de pensar o fundamento da metafísica em diferentes vias do questionamento, superando-a desde a verdade de seu acontecimento historial. Em consonância com esta superação, a identidade deste pensamento também se faz ver no esforço radical, desde Sein und Zeit, de pôr em questão a essência do homem para aquém da histórica determinação animal rationale, (HEIDEGGER, 2003c, p. 3) para enviá-lo numa experiência de um pensamento porvindouro capaz de lançá-lo para além das determinações atuais da história em que se consuma a metafísica da subjetividade nas vicissitudes da maquinação das vivências e no império da técnica. É o que esclarece Heidegger (1992), em um importante curso invernal (1937/38), em que é exposto o sentido da radicalização de seu pensamento enquanto o questionamento da verdade do ser:

É preciso acentuar sempre mais uma vez mais: na questão acerca da verdade aqui levantada, não é importante empreender apenas uma alteração do conceito de verdade até aqui, nem apenas realizar uma complementação para a representação corrente. $O$ que está em questão é uma transformação do próprio ser do homem. Essa transformação não é exigida por intelecções psicológicas ou biológicas - o homem não é aqui objeto de nenhuma antropologia. Ao contrário, o homem encontra-se aqui no aspecto mais profundo e mais amplo, no aspecto propriamente fundamental, o homem na sua relação com o ser (Sein), isto é, na viragem (Kehre): o ser (Seyn) e sua verdade em relação com o homem. A determinação da essência da verdade é acompanhada pela transformação necessária do homem. (HEIDEGGER, 1992, p. 214; tr. por., p. 270-271)

Neste horizonte que se abre com a Kehre, encontra-se o presente texto, a saber, na perspectiva de considerar a liberdade dentro do horizonte de questionamento da verdade do ser e mostrar alguns aspectos que podem levar a tomar o tardio pensamento heideggeriano como fenomenologia da liberdade em um sentido bastante específico, a saber, histórico-essencial, conforme a elaboração da questão do ser enquanto Ereignis 4 . Contudo, faz-se de antemão a ressalva que a mesma

\footnotetext{
${ }^{4}$ A discussão que aqui se elabora pressupõe uma investigação mais ampla em que se discute o sentido desta palavra guia para o pensamento heideggeriano (RAMOS, 2015). Remeto o leitor também para uma profunda 
International Journal of Phenomenology, Hermeneutics and Metaphysics

interpretação deverá ser também possível para o pensamento que se cumpriu até os anos 30 no itinerário de Heidegger, dentro dos limites da elaboração da questão neste período. Nesta etapa necessária, este pensar se define ainda a caminho “da liberdade ek-sistente e desta para a verdade como encobrimento e errância", (HEIDEGGER, 2004g, p. 202; tr. por., p. 214) ${ }^{5}$ como está na conclusão da Wahrheitsvortrag de 1930. Sem grandes pretensões, o presente texto pretende colocar a questão da liberdade à luz de algumas noções e definições do intricado arcabouço conceitual daquilo que Heidegger nomeou seinsgeschichtliches Denken, o pensamento da história do ser.

Com esta expressão, não se afirma que o intento de tal pensar seja o de fazer uma investigação historiográfica do ser, mas indica-se que este, em sua vigência, é o acontecimento oculto que envia e destina a história. Portanto, é a história que pertence ao ser, ao favorecimento que liberta, em dada época, particular determinação do ente no seu todo ao deixá-lo surgir e, assim, cria a história. (HEIDEGGER, 2004b, p. 59-60) Históricos, então, não são o feitos livres dos homens nem os fatos passados descritos pela história universal, aquela que é produto de certa

aproximação à questão do Ereignis, uma série de conferências pronunciadas pelo Prof. E. CARNEIRO LEÃO (2015). Acentua-se que esta é uma palavra essencial, que tenta dizer a essência enquanto a vigência do ser desde o seu acontecimento histórico. Por isto, Heidegger (2009, p. 170) afirma que Ereignis é uma anfängliche Wort, uma palavra propiciadora que nomeia o favorecimento que inaugura a história ao destinar o homem com o seu mundo. Ela é o desdobrar mesmo desta inauguração e ressoa no acontecimento de apropriação do homem em consonância com dado envio histórico. Nesta direção, a rigor, a palavra encontra-se aquém da compreensão metafísica de nome como sinal portador de sentido, significado, passível de ser enunciado verbal, gráfica, gestual ou silenciosamente. Não é sujeita à elocução nem ser silenciada para dar-se em seu sentido propiciador e "ação" inaugural. Além disto, como ela nomeia o favorecimento e a concessão pela vigência do ser da propriedade da existência histórica dos homens, do levante de uma determinação do ente no seu todo mediante a participação humana, que só se destina mediante a entrega e a pertinência dos homens à atribuição apropriadora e destinadora, a palavra guarda em si um jogo contínuo de passagem de um ao outro, do princípio inaugurador ao homem e vice-versa. Ela preserva uma oscilação permanente entre apropriar e deixar ser apropriado, entre acontecimento apropriador e propriedade, entre favorecimento da origem e entrega do homem e todas as coisas à concessão do favorecimento, o que cria um vocabulário de muitas nuances semânticas, rico em múltiplos significados (HEIDEGGER, 2009, p. 147-170). Entre tantos, a presente investigação se guia pela seguinte "definição" de Ereignis: "Die lichtend bergende Hut der Wahr" (HEIDEGGER, 2013, p. 57), em livre tradução, a custódia clareadora e abscôndita da salvaguarda da verdade. Veja também a nota 11.

${ }^{5}$ Esta passagem não exprime um avanço, um progresso teórico-filosófico que se expressaria na mudança de opinião ou posicionamento do sujeito-autor da obra em questão. Pelo contrário, ela nomeia um passo atrás, somente pelo qual se salta dentro da questão da verdade do ser. Neste sentido, a conferência Wom Wesen der Wahrheit é retroativa, visa um retrocesso ao fundamento da metafísica e apenas nesta direção o estágio da elaboração da questão fundamental possui o significado de avanço. Precisamente, seu movimento de questionamento é o retorno da guinada, a volta para trás da reviravolta (rück-kehrend) em direção ao mais digno de ser pensado, a saber, a clareira do ser como proteção, o sítio originário da liberdade (HEIDEGGER, 2013, p. 20). É necessário recordar, porém, que a passagem não se cumpriu desde o projeto de Sein und Zeit, não obstante nesta obra já se intentava a superação da metafísica e procurava-se adentrar na questão da verdade do ser, na via que passava necessariamente pela liberação da liberdade da existência humana como ek-sistência. Deste modo, enquanto dá um passo preparatório necessário à guinada para trás, o tratado logra encontrar um caminho que avança para dentro da questão fundamental. As razões que a impediram a passagem aparecem, em várias alusões, em Brief über den Humanismus (HEIDEGGER, 2004h, por exemplo, p. 343-344).

Sobre abrirfendas, cravar o chão da existência: verdade e liberdade no pensamento tardio de Heidegger 


\title{
Aoristo)))))
}

International Journal of Phenomenology, Hermeneutics and Metaphysics

ciência, mas sim os desdobramentos que desenrolam desde a vigência do ser. Os feitos humanos e o ser humano são históricos conquanto a traduzem e a guardam à medida em que os homens, na sua liberdade ek-sistencial, dão apoio ao surgimento da totalidade do ente, o que significa permanecer na proximidade da verdade do ser - enquanto guarda e cuidado do ser, da liberdade do ser, como será acenado, a "eksistência é morar ek-stático na proximidade do ser". (HEIDEGGER, 2004h, p. 343; tr. por., p. 356) A decisão persistente de permanecer neste cuidado e proximidade terá, certamente, algo a dizer sobre a essência da humana liberdade, mesmo que isto custe ao homem conformar a sua existência como a salvaguarda da "ferida originária que nasce juntamente com o desvelamento do ser". (HARADA, 1970, p. 56) Mas por ser o encobrimento do favorecimento, a verdade é dissimulada e a história, errante, desdobra-se como o conjunto de peripécias e vicissitudes humanas. Assim, a proximidade é vivida no distanciamento da vigência inaugural da história, porém, junto ao ente, mediante a busca incessante de dominá-lo por métodos de asseguramento e estratégias de maquinação. Contudo, é no seio da errância que se experimenta o mistério da vigência propiciadora da história, precisamente, no salto que gira para o abscôndito das origens e, então, como o que se retrai. A errância, como reverberação dissimulada da vigência do ser, é provocação a um pensar originário e, ao mesmo tempo, convite àquela vasta e profunda transformação do ser do homem. Nestes envios e desvios da destinação histórica, portanto, o homem é interpelado para outra relação com à sua própria liberdade: cravar a sua existência no chão do fosso abissal. É o que necessita, pouco a pouco, deixar aparecer de maneira mais evidente.

\subsection{O ÂMBITO DE ELABORAÇÃO DA QUESTÃO: O FUNDAMENTO DA LIBERDADE HUMANA}

Antes de expor a questão da liberdade humana na perspectiva da íntima e decidida relação do homem com o ser, pensada a partir acontecimento da verdade como a propiciação velada de uma clareira protetora para todos os entes, deve-se esclarecer melhor o âmbito de elaboração da questão. Já o sabemos, ao menos de modo ainda vago, que este é o da ek-sistência humana, porém, iluminada e transformada pelo acontecimento da verdade do ser, como proteção e errância. Para precisar este campo originário da investigação, explicita-se o fio condutor, o qual, mais abaixo, será formulado à guisa de uma expressão diretriz. Negativamente, o eixo condutor se deixa formular, dizendo que a liberdade não é pensada a partir de uma reflexão ética, no sentido usual e vastamente disseminado do termo. Aquilo que aqui se visa, pois, não é descrever a estrutura do ato moral e, portanto, não pretende se aproximar do pensamento tardio de Heidegger, buscando nele a tematização da causalidade da liberdade ou as condições de possibilidade da vontade livre. Com efeito, a liberdade não será tratada como algo pertencente à vontade ou como o fruto

\author{
Daniel Rodrigues Ramos \\ Toledo, v. 4, n・1 (2021) p. 105 141
}




\section{Aoristo)))))}

\section{International Journal of Phenomenology, Hermeneutics and Metaphysics}

do querer e do arbítrio humano. Tudo isto é, de certo modo, uma repetição mais longa de uma alusão acima. Mas estas observações de caráter negativo possuem algo de positivo como que sendo o seu avesso: elas mostram que o âmbito da liberação da questão verdade não será o da metafísica greco-cristã nem a da moderna subjetividade, pois ambas já pertencem à história do ser. Cada uma destas metafísicas, pois, move-se em uma determinação epocal da essência da verdade (ómoiwsis, adaequatio, certitudo) enquanto correspondências ao sentido do ente no seu todo (entre outros, idغ̇a, oủsia, غ̇nérgia, substantia, actualitas, creatio, subjectum, vontade de potência) que lhe servem de fundo para suas noções e compreensões fundamentais. A partir deste fundo, a vontade (em seu querer imbricado com a razão, o amor, o poder, o espírito) se impõe como livre, como fim em si mesmo e, com isto, é também na base e proteção deste fundo que o homem se ergue como criatura, sujeito, além-do-homem. Porém, as metafísicas possuem o seu fundo configurado a partir de como o ser se dá epocalmente. (HEIDEGGER, 2007a, p. 11) Por esta razão, não se instala desde estas metafísicas uma autêntica compreensão da liberdade humana que, como dito, só se apreende a partir da sua relação com a iluminação velada da verdade do ser e sem a qual não se transforma a essência metafísica do homem. Pelo contrário, delas apenas resulta uma interpretação antropocêntrica da liberdade, já que a história da metafísica é o caminho do levante do homem, cuja figura por excelência será a do ser-sujeito, aquela que a modernidade entendeu ser a concretização plena do ideal humanístico do homem como medida (pelo cálculo da razão representacional) de todas as coisas ${ }^{6}$. Com esta medida, o homem mede também a sua própria liberdade como propriedade e produto seu; e isto para assegurar-se como sujeito autônomo.

Se a liberdade não será tomada como uma faculdade, entre tantas outras, do sujeito humano, no entanto, deverá aparecer como aquilo que há de mais próprio para caracterizar o ser do homem na sua verdade, isto é, para revelar a estrutura profunda do seu modo de ser. Pois estaria vedado encontrar o fundamento das condições de possibilidade da existência humana se faltasse uma fenomenologia da liberdade, isto é, o aparecer do ser-livre, o que é possível desde o fundo em que reside o princípio da história, então, do fundamento do qual sempre eclode, cada vez, o todo em que homem e mundo se assentam. Com esta falta, ao ser humano não estaria tão somente barrado o caminho para determinar-se, tanto em relação aos

\footnotetext{
${ }^{6}$ Assim, apesar das transformações pelas quais a metafísica consuma sua destinação, a saber, da essência da verdade, da determinação do sentido do ente no seu todo e, consequentemente, da essência metafísica do homem, a figura do homem grego ainda continua sendo o modelo de referência do homem ocidental e o paradigma para pensar o sentido de sua liberdade e sua vontade de domínio em dimensão planetária (HAAR, 1990, p. 193). Deve-se, no entanto, fazer a ressalva que, para tanto, as experiências fundamentais do ente do pensar grego e, mais tarde, da metafísica medieval teve que ser lida, pela modernidade, a partir de uma interpretação humanista que a impede de ver o sentido e as fontes originária do pensamento grego (HEIDEGGER, 2003b, p. 103). O caráter antropocêntrico desta interpretação é explicitado na hermenêutica, empreendida por Heidegger (1998), na preleção Der europäische Nihilismus, do dito de Protágoras, em confrontação com o sentido que lhe dá a modernidade em base da determinação da essência humana como subjetividade e, deste modo, fundamentum absolutum inconcussum veritatis.
}

Sobre abrir fendas, cravar o chão da existêncía: verdade e liberdade no pensamento tardio de Heidegger 
aspectos da sua existência singular quanto histórica. Mas também estaria impedido o caminho para o questionamento da filosofia, que, sendo um perguntar pelo todo, pelo ente na sua raiz, é sempre radical; como dizia Husserl (2009, p. 72, tradução minha), "Filosofia, porém, é, segundo a sua essência, ciência dos verdadeiros

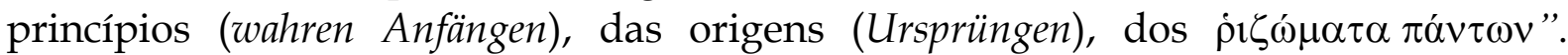
Filosofar é questionamento que tenta, cada vez de novo, assentar o que se questiona no todo, também quando interroga a liberdade humana. E quanto este questionar possui o sentido de superação da metafísica, trata-se de devolver as raízes do questionado ao solo esquecido e ao elemento nutriente nele resguardado, inclusive a própria metafísica com suas noções e palavras fundamentais. (HEIDEGGER, 2004i, p. 365)

Para tanto, Heidegger já havia atentado na preleção de 1930, Vom Wesen der menschlichen Wahrheit. Neste escrito, evidencia-se que pergunta pela liberdade, enquanto é experimentada como uma tarefa de singularização, é a questão que permite a cada homem compreender o todo como todo e, ao mesmo tempo, chegar à raiz da existência. (HEIDEGGER, 1994a, p. 130) Já do ponto de vista da metafísica, a liberdade não é somente recusa ou afastamento do homem do todo em vista, na linguagem dos modernos, da autônoma determinação de si mesmo, isto é, a coragem de renunciar à necessidade dos processos naturais, das prévias determinações sóciohistóricas, às imposições dos outros, das instituições, das religiões, bem como àquelas provenientes de todas as coisas às quais os homens se encontram acorrentados pelo desejo, prazer e diversos "amores". Ao ser-livre pertence necessariamente boa dose de autossuficiência, pois, como já lembrou Aristóteles (2009, 1097b 20), as formas plenas de viver a vida humana apenas se concretizam sob o princípio da autarquia, em base de certo bastar a si próprio na realização de si mesmo. Porém, tal busca de tal independência é apenas o conceito negativo do ser-livre (liberdade de) e a função de qualquer conquista da autarquia ou da autonomia é, no final, senão em (re)estabelecer outra vinculação com o todo (conceito positivo: liberdade para) ${ }^{7}$.

\footnotetext{
${ }^{7}$ Tal ambiguidade entre liberação e vinculação com o todo presente no conceito metafísico de liberdade pode ser apreendida, nas suas linhas gerais, nas considerações prévias da preleção de 1930, Wom Wesen der menschlichen Freiheit, de Heidegger (1994a). Tendo por base estas páginas, pode-se acenar essa problemática do seguinte modo: o homem é, na sua essência, possibilidade. Nos aspectos essenciais, as suas resoluções e decisões mais íntimas são independentes da necessidade dos processos da natureza e das prévias determinações do passado histórico. A realização de sua existência, então, é independente do mundo, embora nele se engaje de um modo ou outro - na perspectiva dos modernos humanismos, tal como no existencialismo sartreano, o homem, em sua possibilidade, é aquilo que ele faz de si; não sendo sua existência necessária nem predeterminada, mas sendo "projeto que vive a si mesmo subjetivamente" (SARTRE, 1973, p. 12), sua liberdade é escolha responsável por si próprio. Enquanto comprometimento com o aparecimento de sua presença contingente neste mundo, sua liberdade é, per se, totalmente independente dos outros e da existência de Deus, por mais que em cada escolha de si esteja englobada toda a humanidade. Esta posição se opõe claramente à compreensão da metafísica cristã, segundo a qual o fundamento do mundo é Deus. Como tal, Deus é a suprema necessidade, pois se todos os demais entes têm em si a possibilidade de ser, o ente divino possui a causa de ser em si mesmo. Por esta razão, como demonstra Tomás de Aquino (1957), na terceira via, Deus é aquele ente em que todos reconhecem ser a "causa necessitatis aliunde", de todos os
}

$$
\begin{array}{r}
\text { Daniel Rodrigues Ramos } \\
\text { Toledo, v. 4, } n^{\cdot 1}(2021) \text { p. 105 141 }
\end{array}
$$




\section{Aoristo)))))}

\section{International Journal of Phenomenology, Hermeneutics and Metaphysics}

Contudo, a estreita conexão entre particularidade da existência singular e a universalidade do todo, que se aparece na manifestação/concretização do ser-livre, poderia ser indicado de outra maneira mais fundamental. Com efeito, cada vez que o homem se compreende ao longo da facticidade de sua existência, não só compreende sua própria singularidade, mas também compreende que esta tarefa de singularizarse e compreender-se, empreendendo uma experiência única de ser e tornar-se a si mesmo no tempo, é tarefa de todo e qualquer homem. É temporalmente que o homem libera a si mesmo, mas também o ser homem como tal, portanto, a humanidade em sua raiz, em toda a sua uni-versalidade. Na sua singularidade, forjada pelo tempo, então, o homem compreende a humanidade como todo, dirige-se à raiz da existência humana, ao uno que vincula todos os homens. Ao mesmo tempo, nesta experiência de singularização do universal e universalização do singular, ele também apreende, na maioria das vezes pré-tematicamente, no decorrer da experiência de liberar e tornar a si mesmo, o fato que o ser se dá e permanece em íntima vinculação com o tempo. Por isto, no auge da preleção acima recordada, conclui Heidegger (1994a, p.; tr. por., p. 159): “a questão acerca da essência da liberdade humana, se nós a perguntarmos de maneira correta, é uma questão que se remete para o todo e, em verdade, trata-se de um remeter-se-ao-todo que é ao mesmo tempo, segundo o seu conteúdo interno, um ir às-nossas-raízes".

Ora, aquilo que é o ente no seu todo, melhor, como ele se torna o que é, surgindo e perecendo, como ele aparece em seu contínuo nascer e morrer, é a questão condutora de toda a história da metafísica. É o questionar desta questão que faz da

demais entes que não podem vir a ser por si mesmos. Em seu necessário existir a se, Deus é a causa eficiente do mundo e de tudo que nele existe e perece. Contudo, cabe ao homem acolher ou não a exigência de Deus como fundamento, não no sentido usual de uma posição ateia, mas que no homem se encontra tanto a possibilidade de voltar para Deus como a de renunciá-lo. Em tudo isto, precisamente, diante do ente no seu todo, o homem é um ser livre por natureza. Liberdade, porém, neste sentido é um conceito negativo, pois diz independência em relação ao mundo e Deus enquanto afastamento do todo do ente. Contudo, o conceito pleno da liberdade negativa só se alcança mediante o esclarecimento de como o homem estabelece necessárias relações com aquilo de que ele se afasta, mesmo quando esta relação é de renúncia. Deste modo, o conceito de liberdade como independência de... converte-se em um estar ligado e, sobretudo, no fundamento da possibilidade de estar-ligado ao todo, em cuja abertura ou fundamento ele decide se vincular a isto ou aquilo como ato da liberdade. Nesta direção, o conceito de liberdade é positivo e diz um ser-para uma vinculação essencial com o todo. Por esta razão, no auge da preleção supracitada, sintetiza Heidegger (1994a, p.131; tr. por., p. 159): “a questão acerca da liberdade humana, se nós a perguntarmos de maneira correta, é uma questão que remete para o todo e, em verdade, trata-se de um remeter-se-ao-todo que é ao mesmo tempo, segundo o seu conteúdo interno, um ir-às-nossas-raízes". Tal é sentido mais radical da liberdade positiva. Kant (1974, p. 59; tr. por., 2003, p. 113), a partir da compreensão do homem como sujeito e em termos da causalidade materialmente incondicionada, expressa-a do seguinte modo: "Mas aquela independência [de toda matéria da lei] é liberdade sentido negativo, porém esta legislação da razão pura e, enquanto tal, razão prática, é liberdade em sentido positivo. Portanto a lei moral não expressa senão a autonomia da razão prática pura, isto é, da liberdade". A partir de outras bases metafísicas, porém, ainda subjetivamente, esta positividade da liberdade é apreendida humanisticamente enquanto a condição humana de ter que realizar o projeto que ele mesmo é mediante o engajamento com toda a humanidade, implicando-se moralmente com as relatividades do mundo e da história de seu tempo, na medida em que as livres escolhas e ações do homem em particular englobam um conjunto de relações com as coisas e demais homens.

Sobre abrirfendas, cravar o chão da existêncía: verdade e liberdade no pensamento tardio de Heidegger 


\title{
Aoristo)))))
}

\section{International Journal of Phenomenology, Hermeneutics and Metaphysics}

metafísica a raiz de todo saber, para usar uma antiga imagem, mas mediante este questionamento também ela enraíza a si mesma no todo, na unidade de todas as coisas. Interpelar a totalidade e cada coisa com esta questão, porém, desde o horizonte esquecido do tempo - projeto originário de Sein und Zeit, mesmo que não logrado - é perguntar pelo solo em que se fincam estas raízes. Solo é fundamento. Então, trata-se da questão fundamental, porém, já não mais entendendo-o como a totalidade, mas sim como o dar-se do fundamento a partir dele mesmo e, nisto, da doação do ser em seu mistério, desde o seu profundo "dinamismo" propiciador histórico. Portanto, como tal, é aquela que se vira para o acontecimento pelo qual o ente, em cada época, ilumina-se em determinada configuração. Se neste fundamento deve se assentar o homem para aparecer como ser-livre e liberador do seu mundo histórico, o acontecer deste fundamento é âmbito originário da investigação da questão da liberdade. É o no livre do fundamento, em seu poder liberador, então, na profundeza oculta do solo, que a essência da liberdade deve ser buscada, mesmo que este apareça desertificado na época do domínio planetário da técnica. Ao fundamento, pensado como o dar-se do ser enquanto favorecimento da totalidade e apoio do homem e mundo históricos, deve pertencer a questão da liberdade humana. E questioná-la nesta dimensão do fundamental, enquanto aquela experiência que transforma o homem por inteiro e de liberação histórica mais profunda do ser do humano, mostra-se como concreta possibilidade de elaboração da verdade do ser e de nela assentar a existência humana.

Com isto, porém, voltamos à outrora vinculação entre a questão da liberdade humana com a questão fundamental. No entanto, a vinculação da possibilidade de revelação do ente no seu todo com a liberação do mais próprio da existência humana tem algo mais, que é expresso nos seguintes termos: “A liberdade não é nada particular entre outras coisas, ela não se encontra alinhavada entre outras coisas, mas é pré-ordenada e impera precisamente sobre o todo do ente. Mas se a liberdade tem de ser buscada como fundamento de possibilidade do ser-aí, então, ela mesma é em sua essência mais originária que o homem. O homem não é senão o administrador da liberdade". (HEIDEGGER, p. 134-35; tr. por., p. 162-163) Mais primitiva que o homem, é a liberdade que se doa como a possibilidade do homem e, isto numa profundeza tal e de modo tão decisivo, que ele não toca o núcleo mais íntimo da estrutura do ser homem se não deixa ser favorecido pelo livre apoio do fundamento. Mas também é e a partir desta antiguíssima liberdade, do livre apoio que todos os entes são liberados, num jogo infindo e riquíssimo entre unidade ou identidade (do fundamento, do ser) e multiplicidades, pluralidades (dos entes), numa profusão de liberalidade. A finitude humana, na realização temporal da possibilidade mais própria da existência, bem como por meio das vicissitudes manifestas ao longo da história de cada homem e de toda humanidade em certa época, apenas tange a profundeza deste solo e, ademais, nutre-se de pequena monta de sua seiva. Porém, é mediante o homem, na medida em que ele se dá ao apoio e empenha na fundação deste apoio - digamos, crava as raízes de sua existência neste solo -, que a liberdade

\author{
Daniel Rodrigues Ramos \\ Toledo, v. 4, n'1 (2021) p. 105 141
}




\section{Aoristo)))))}

\section{International Journal of Phenomenology, Hermeneutics and Metaphysics}

aparece desde sua fonte arcaica. Assim, jogando o jogo misterioso da liberalidade do fundamento, o homem torna-se o que é em suas raízes: o lugar de revelação da liberdade como tal, pois é o ponto de passagem do ser para o ente no seu todo. Aquele algo a mais, portanto, é que a liberdade atravessa o modo de ser do homem, desde o fundamento do ente na totalidade. Deste modo, ele não é somente o único ente capaz da liberdade e experimentá-la desde as origens. Ele também o é enquanto o existente pelo qual, na estrutura do fundamental do seu modo de ser, todos os demais entes se fazem "livres". Na duplicidade deste sentido, o homem é Da-sein, modo de ser que insiste aí, na fundação do fundamento, tornando-se o espaço para que o último possa se manifestar em sua temporalidade histórica.

Em síntese, grosso modo, mediante a existência humana, por ser essencialmente livre, faz-se visível a entidade no seu todo e a diferença de cada ente em particular. Deste modo, ela é essencialmente descobridora. Nela, desvela-se o fundo - a aberta iluminadora do ser - que faz aparecer cada ente. De igual modo, também os elementos particulares de cada ente se revelam, no fundo ek-sistencial que os sustenta, intricados a partir do nexo estabelecido entre o sentido unificador e os significados ônticos específicos e secundários. A pergunta pela liberdade, se conduzida de modo radical, portanto, é a questão do sentido (da verdade) do ser, mas também do fundamento da existência humana, na medida em que é, de igual modo, tematização do que cunha o ser humano desde a raiz: a possibilidade de deixar-ser tudo manifestar-se em unidade da identidade e na ruptura da diferença. De modo mais breve, a liberdade humana é a da condição originária de possibilidade do desvelamento (Entborgenheit) do ente em particular a partir do todo. Deste modo, se a verdade tem a ver com o trazer o ente à tona no que e como é, a questão da liberdade necessariamente se liga essencialmente, desde as finitas experiências da humanidade com o fundamento, com a questão da verdade.

Nisto se faz patente que a liberdade é deslocada para a propriedade da existência humana. Um movimento que já estava explícito em Sein und Zeit, a partir do momento que a liberdade é conduzida para a abertura (Erschlossenheit) da existência, sobremaneira, ao descrever fenomenologicamente o existencial da descoberta (Entdeckenheit). Neste existencial, considera-se tanto a possibilidade do Dasein descobrir quanto a de velar, (HEIDEGGER, 2006a, p. 219-222) de ser próprio e impróprio na realização da possibilidade de permitir tudo viger livremente. É que o Dasein existe, ao mesmo tempo, na possibilidade de liberar $e$ não liberar a si mesmo; a existência se perfaz, pois, própria e impropriamente. Por isto, é capaz de deixar encoberto tanto a si mesmo para si, quanto os modos de ser dos demais entes. Assim, é que o homem, desde a estrutura fundamental de seu ser, vigora tanto na verdade quanto na não-verdade, pois seu existir é originariamente descobridor e velador. Todavia, nesta recondução da verdade ao caráter (des)cobridor da abertura da existência, o fenômeno da liberdade permanece não tematizado explicitamente em sua proveniência misteriosa, em seu acontecimento propiciador da história, mesmo que em Sein und Zeit claramente se leva a cabo a ideia que a facticidade do ser-nomundo é tarefa de constante liberação, na medida em que tem que permanentemente

Sobre abrirfendas, cravar o chão da existêncía: verdade e liberdade no pensamento tardio de Heidegger 


\section{Aoristo)))))}

\section{International Journal of Phenomenology, Hermeneutics and Metaphysics}

revelar a si para si mesmo, a si com os outros, o mundo em múltiplas camadas (da ocupação cotidiana, da convivência e de significação de tudo isto a partir de próprias e históricas possibilidades existenciais), bem como os entes que nele se encontram a partir de uma compreensão originária do tempo e historicidade da existência humana. Neste ponto do caminho em que se elabora a questão do sentido da verdade do ser, ainda não se pensou que o solo de todas as descobertas humanas é o que se oculta, justamente para que o ser-livre do homem apareça em poder descobridor, como jogo da liberalidade do deixar-ser. Por meio deste jogo, também a verdade se dissimula e sua existência histórica é errância. Não obstante este limite, a verdade da liberdade deve ser pensada em conexão com a ideia fundamental que a existência se perfaz descobrindo a si mesma e, ao mesmo tempo, os entes que se encontram no mundo circundante. Liberdade é, pois, primeiramente, desvelamento enquanto estrutura ontológico-fundamental da existência. E se há deturpação neste desvelamento, transformando-o num velar, este é ainda um descobrimento, claro, desvigorado de sua plena potencialidade. E isto porque a existência se mostra, na maioria das vezes, no modo de um desfalecimento da perfectibilidade da sua possibilidade mais própria. Nesta condição cotidiana, a liberdade parece exclusivamente promover a manifestação, evidenciar que elimina toda sombra. Aparece, nas maneiras mais defasadas e corriqueiras de concebê-la, como um feito do homem que, ao conduzir autenticamente a sua existência, arranca-a das trevas das prisões cotidianas, como se originariamente tanto a propriedade da existência se determinasse a partir da autenticidade das suas escolhas subjetivo-particulares quanto a essência da liberdade pertencesse ao (lúcido) poder e querer do sujeito humano.

Mas a liberdade humana não é só iluminada, luminosa, iluminante e, enquanto situada na clareira da abertura transcendental da existência, não é tão somente um poder-ser que desvela ao deixar cada ente emergir na sua verdade. A liberdade possui suas sombras, escuridões, pois é também um poder velar que inscreve no eksistir o caráter de não-ser-verdadeiro (o não-ser-descobridor), na medida em que os homens revelam a si mesmos e os outros como se fossem entes já dados dentro do mundo e, então, como se a liberdade não fosse uma tarefa essencial da sua existência, isto é, não tivessem que liberarem o seu ser-livre. Ocultam os homens a si mesmos o sentido de sua facticidade e finitude quando eles corriqueiramente se comportam com a temporalidade da própria singularização como se o tempo fosse uma sucessão de momentos e, apesar de fugazes, ainda contabilizáveis; ou quando a vivem como uma subjetiva-particularista vivência interna. As sombras também imperam no mundo erigido mediante as plurais modalidades humanas de ser-descobridor (entre elas, a produção e a criação, a ação, o pensar e a teoria), no qual, em nome de clareza da objetividade necessária aos processos técnicos, nada mais é revelado para além ou aquém do que é dado à mão no operar e calcular. De igual modo, existem na nãoverdade, quando os homens lidam apenas com o verdadeiro e somente se ocupam em liberá-lo em todo fazer e não fazer e, consoante ao este comportamento

$$
\begin{array}{r}
\text { Daniel Rodrigues Ramos } \\
\text { Toledo, v. 4, } n^{\cdot 1}(2021) \text { p. 105 141 }
\end{array}
$$




\section{Aoristo)))))}

International Journal of Phenomenology, Hermeneutics and Metaphysics

cotidianamente privilegiado, também se ocupam da verdade como se fosse apenas um conceito, uma equivalência entre a realidade e o que dela se diz. Porém, em tudo isto e muito mais, a existência é descobridora, claro, desde concreto deixar-ser em cujo sentido de realização cada ente não vem à luz própria ou originariamente, mas como aquilo que não é: o deixar-ser rouba, na maioria das vezes, a verdade do que mediante ele é descoberto. Assim, é inerente ao poder iluminar pertencente à facticidade humana a possibilidade de sombrear, mascarar e dissimular. Por isto, o homem descobre a si, o seu mundo e as coisas nele enredadas a partir de sentidos deturpados e significados defasados que, de descobertas em descobertas, tecem as peripécias da história, sedimentando densas camadas de sentido sobre a manifestação do ente no seu ser.

Desta condição de ser-na-não-verdade, do não-ser propriamente e, por isto, da presença de um essencial poder encobrir na liberdade humana já se sabia em Sein und Zeit, embora ainda ali não se tenha ainda pleno saber do significado deste nãoser, que aliás faz parte da longa história da ólinqeia, alétheia. (HEIDEGGER, 1997, p. 109) Nesta obra, pois, é categoricamente afirmado: “'O Dasein é e está na verdade' também inclui, de modo igualmente originário, que o 'Dasein é e está na nãoverdade'". (HEIDEGGER, 2006a, p. 222; tr. por., p. 290) A existência, em sua raiz mais íntima, é encobrimento do desvelamento. Se um ocultar está na raiz das descobertas humanas ou, como será acentuado na conferência de 1930, se "justamente na medida em que o deixar-ser sempre deixa o ente a que se refere em cada comportamento individual e, com isto, o desoculta, ele encobre o ente na totalidade", (HEIDEGGER, 2004g, p. 193; tr. por., p. 205) faz-se evidente que a essência da verdade mesma reside na ocultação. A essência da verdade é a nãoverdade; formulação negativa que se impôs cada vez mais no pensamento de Heidegger, de tal modo que, sem a negação deste "não" fica bloqueada a integral elaboração da fenomenologia da liberdade a partir do pensamento tardio de Heidegger, certamente porque este "não" é aceno de "algo" extraordinário e extremamente originário na vigência histórica do ser. Como, então, entender esta formulação negativa? Uma resposta para esta pergunta é possível caso não se queira eliminar negatividade, entendendo que a não-verdade ocorreria ao lado da verdade, sendo assim possível preveni-la ou remediá-la. Ao contrário, ela não é meramente uma mera privação ou deformação da verdade. Deste modo, este "não" não resulta de um limite do conhecimento, nem dos limites e deficiências do agir e da moralidade, como se estivesse no arbítrio humano tanto deixar-ser e não-deixar-ser. Em deixando ser, essencialmente, o homem também permite que o ente na sua totalidade se encubra e isto de modo essencial e inevitável. No momento, porém, é dado apenas ressaltar que na formulação negativa revela-se uma ambiguidade. De um lado, o "não" da não-verdade aponta para um modo de abertura da existência humana, que impede o homem a realizar a estrutura do fundamental do seu ser como o aí em que todos os demais entes se fazem "livres". Nesta direção, a abertura é um fechamento e encobrimento da facticidade do homem para ele mesmo e, inevitavelmente, a tônica da história será a errância. Por outro lado, o não-ser é modo

Sobre abrirfendas, cravar o chão da existêncía: verdade e liberdade no pensamento tardio de Heidegger 


\section{Aoristo)))))}

\section{International Journal of Phenomenology, Hermeneutics and Metaphysics}

originário de vigência, a presença de uma ausência, assim, o "não" indica, em vez de aniquilação, o voltar-se ou guinada para o cerne da abertura daquilo que se desvela na totalidade: não-ser é a vigência do "não", do nada como retraimento. Aponta, assim, para o mistério do ser. Neste sentido, se há um fechamento, este possui o sentido de conceder-se do fundamento enquanto propiciação velada de uma clareira protetora para todos os entes; ao mesmo tempo, é o recolher-se do homem na irradiação da claridade da verdade do ser que, o aberto do escuro, do abscôndito. Se assim for, a tonalidade será outra, a do encanto com o oculto ou com o ardor da claridade. Mediante o arrebatamento deste fascínio, não-ser significa o abrir-se da existência atravessada, por inteiro, por um mistério esquecido, porque fundamentada no apoio da ocultação. (HEIDEGGER, 2003c, p. 33; 2004g, p. 194)

No fenômeno da verdade, então, há um jogo de desvelar e encobrir. Se o último é o cerne do primeiro, o mistério não pensado e experimentado em toda a história da àlńqeia, vigora um nada no seio do desvelamento, mas porque a verdade mesma tende a se recolher como o fundamento libérrimo que tudo suporta e, assim vigorando, deixa que tudo se ilumine, venha a ser. Em especial, o homem como serlivre. De outro modo, "a verdade significa o ocultar iluminador (lichtendes Bergen) enquanto traço fundamental do ser (Seyn)". (HEIDEGGER, 2004g, p. 201; tr. por., p.213 $)^{8}$ Então, fundamentalmente, as sombras e escuridões que persistem em todo humano deixar-ser, se compreendidas desde o cerne do acontecimento histórico da vigência do ser, depende do modo mesmo como a verdade, na sua liberdade, doa-se como ocultamento e proteção. Na liberdade que toca ao humano, cabe-lhe tão somente cuidar deste velamento e, neste cuidado, iluminá-lo, deixando-o aparecer como tal. Na guinada da reviravolta para o fundamento da própria liberdade, o homem realiza sua estrutura profunda, e também deixa o mistério, em todas as suas obras e feitos, ser o revelação de sua ocultação.

A liberdade humana, portanto, não pode escapar ao imperativo daquele "não", do nada que se instaura com a ocultação da verdade do ser. O velamento é a questão central, também da liberdade. Todavia, de um modo tal que o velamento não impede a liberação da liberdade, mas é nele que o desvelamento haure a sua possibilidade mais íntima. Descobrir, deixar o ente aparecer no sentido que lhe é próprio, é também ocultar o solo de aparecimento de sua verdade ôntica. Deste modo, paradoxalmente, é na intimidade da verdade do ser, a ocultação, que a questão da liberdade humana encontra seu originário âmbito de elaboração e demonstração de sua essência como poder manifestar, isto é, como "deixar-ser ek-sistente que

\footnotetext{
${ }^{8}$ Note-se que na frase citada, o termo traduzido por velamento não é o usual substantivo Verbergung, mas Bergen. Assim, o traço essencial da verdade do ser é revelar-se na iluminação de um abrigo. Trata-se, com efeito, de um velar, porém o termo Bergen indica, com muita força, que velar possui o sentido de cuidar, proteger e amparar, abrigar e pôr a salvo. Por isto, Heidegger (2013, p. 19) anota a respeito da verdade: "Wahrheit é Wahr-heit". Nesta formulação Wahr- não é somente o verdadeiro, mas também aquilo que é tomado com cuidado, defendido e salvaguardado na sua essência. Com efeito, nisto o pensador sublinha a íntima proximidade entre seguintes termos alemães: o adjetivo wahr (o verdadeiro, o verídico), o substantivo Wahrheit (verdade) e o verbo wahren (cuidar, defender, salvaguardar).
} 


\section{Aoristo)))))}

International Journal of Phenomenology, Hermeneutics and Metaphysics

desencobre o ente". (HEIDEGGER, 2004g, p. 192; tr. por., p.204) Pois deixar ser manifesto não é tornar amplamente acessível, isto é, devolver o ente à posse da compreensibilidade sem reservas, a uma suposta e trivial evidência, mas que é senão o resultado de uma ingênua clarificação ou de uma cega simplificação que só o dispõe como algo acionável; não é entregar às obviedades de um saber que pretensamente tudo dá por objetivo e certo. Mas é preservar a verdade do ente e abrigá-la contra estas correntes distorções. Nesta direção, é devolver cada coisa para mistério de sua verdade, restituindo-a à sua proveniência. Nisto residiria a verdade da liberdade humana que, pensada a partir da doação da origem, é a liberdade do ser que se instaura, libérrima e liberalíssima, justamente com a ocultação da sua verdade. A verdade da liberdade (humana) é a liberdade da verdade (do ser), poder-se-ia resumir o problema central de onde colocar o âmbito adequado de elaboração da questão da liberdade. Eis porque o aparente paradoxo entre revelar e esconder poderá ser resolvido não pela sua eliminação, mas mantendo-o na força de seus contrastes, como neste trecho da conferência Die Frage nach der Technik (1953):

A liberdade tem seu parentesco mais próximo e mais íntimo com o dar-se do desencobrimento, ou seja, da verdade. Todo descobrimento pertence a um abrigar e esconder. Ora, que a liberdade é o mistério, um encoberto que sempre se encobre, mesmo quando se descobre. Todo descobrimento provém do que é livre, dirige-se ao que é livre e conduz ao que é livre. A liberdade do livre não está na licença do arbitrário nem na submissão a simples leis. A liberdade é o que aclarando encobre e cobre, em cuja clareira tremula o véu que vela o vigor de toda verdade e faz aparecer o véu que vela. A liberdade é o reino do destino que põe o desencobrimento em seu próprio caminho. (HEIDEGGER, 2004a, p. 29; tr. por., p. 28)

O descobrimento encaminha, sempre mais, para o encobrimento, para que a liberdade seja abrigada na sua essência. Oculta-se para que esta essência vigore como o livre que libera cada ente no seu em seu ser e o instaurar do todo em que a liberdade humana se enraíza. Tentando dizer acontecimento da essência partir deste mistério, ou seja, desde o ocultamento abrigador como o núcleo da vigência da verdade, forçamos as possibilidades de expressão com a seguinte formulação: a verdade da liberdade é a liberdade da verdade. Importante realçar que o núcleo da formulação é o verbo ser, a partícula "é". Pois ela nomeia a intimidade da copertinência e mútua interdependência entre o primeiro e o segundo modos de vigência que ela liga. A liberdade da verdade, o segundo modo, fende a existência humana, já que ela se doa como o salto da ferida originária. A verdade da liberdade, enquanto a experiência de concretização do ser-livre do homem, é o cravar da existência neste solo fendido da existência humana. $\mathrm{O}$ caminho para o alto, do levante do homem como existência transcendental, e o caminho para baixo, o salto do ser para dentro do seu fosso abissal são um único acontecimento e a criação do mesmo solo.

Sobre abrirfendas, cravar o chão da existêncía: verdade e liberdade no pensamento tardio de Heidegger 


\title{
Aoristo)))))
}

International Journal of Phenomenology, Hermeneutics and Metaphysics

\section{A VERDADE DA LIBERDADE É A LIBERDADE DA VERDADE 2.1. A VERDADE DA LIBERDADE}

A verdade da liberdade é a liberdade da verdade. Com isto, não se faz outro que deixar ressoar o sentido fundamental da verdade, tal como se anota no final da Wahrheitsvortrag a partir do momento que a Kehre se impôs no itinerário do pensamento heideggeriano : "a essência da verdade é a verdade da essência" (das Wesen der Wahrheit ist die Wahrheit des Wesens). Com esta virada, tenta-se superar a tradicional definição de verdade como correção ou adequação, não obstante se busque o fundamento originário desta determinação metafísica da verdade. Antes, como dito, a verdade é compreendida como a vigência de um mistério que perpassa toda abertura da existência humana, a saber, um encobrimento arcaico e fontal do ente na sua totalidade. A conferência move-se na compressão de que esta vigência perdura ocultada, na história dos desdobramentos da $\dot{\alpha} \lambda \eta \dot{\theta} \theta \varepsilon \iota \alpha$, no desvelamento; que ela se protege, de um modo ou outro, nos desocultamentos dos levantes do ser no seu todo em qualquer época. (HEIDEGGER, 2013, p. 24) Esta proteção, seja na forma de dissimulações das errâncias ou no abrigo da recusa, é possível em virtude da estreita e íntima conexão entre verdade e liberdade e existência. Esta última noção, pois, entra como interstício, que se constitui como o acontecimento da abertura ou a experiência histórica de ter que manter, nesta abertura, a clareira da origem, sustentando o hiato entre ser e homem como o livre em que dá o desvelamento da essência epocal dos entes. Por isto, a verdade da essência dos entes é, antes, a vigência da verdade do ser, instaurada pela participação do homem neste acontecimento como ser-livre.

Como o elo desta conexão que se protege como o mistério mais enigmático para o pensamento, a existência não é só a manifestação luminosa, nem só o obscurecimento da verdade. Antes, é o "aberto do obscuro" (Offene des Dunkels), (HEIDEGGER, 1997, p. 109) o entre do acontecimento de um mistério abissal, que une e deixa vir ao encontro tanto o homem quanto o ser em uma nova ou tão antiga essência ou verdade de ambos, ainda desconhecida. Ela é o entre da intimidade de único acontecimento da verdade, que, todavia, se deixa dizer, na maioria das vezes, a partir de dois polos ou com significado duplo (HEIDEGGER,1997, p. 117): de um lado, a fala silenciosa da liberação do mistério como o aprofundar e recolher de si mesmo em profundezas abissais; de outro, a fala também silenciosa do elevar-se do modo de ser do homem, enquanto um ente que se encontra junto aos demais entes, liberando para estes um entre manifestativo, prévio e primordial ou, como está em Sein und Zeit, de uma abertura descobridora. Na existência, então, a liberdade é tanto liberação do mistério para ser mistério (a verdade do mistério), quanto do homem para ser ele mesmo e, junto a ele, do mundo com os demais entes (a verdade homem), num jogo de íntima copertinência de claro e escuro, iluminação e obscurecimento.

\author{
Daniel Rodrigues Ramos \\ Toledo, v. 4, n*1 (2021) p. 105 141
}




\section{Aoristo)))))}

International Journal of Phenomenology, Hermeneutics and Metaphysics

Por razão desta duplicidade essencial, no desvelamento (a Entborgenheit) que a existência humana promove, na medida em que esta última é compreendida como ek-sistência transcendental que libera o ente para ser si mesmo, acontece também um profundo ocultamento, a Verborgenheit. Por graça da primeira dimensão, o desvelamento, faz-se evidente o privilégio da existência humana, na medida em que, somente nela e por ela, não isto ou aquilo chega à verdade, mas sim nada menos que o ente no seu todo. Sem a abertura da existência humana, então, não aconteceria aquele descobrimento que os gregos já chamaram $\dot{\alpha} \lambda \eta \dot{\theta} \theta \varepsilon \iota \alpha$, de tal modo este privilégio guarda em si a possibilidade, presente, passada e futura da história da verdade. De um modo ou outro, deturpando, dissimulando ou protegendo o mistério, o homem ocupa um lugar preponderante na história da verdade em relação aos demais entes. Claro que se trata de uma preponderância que chega a nós, seres humanos, precisamente, ao nosso ser, como uma convocação inexorável e uma tarefa inalienável de tudo guardar no aberto da verdade e nele salvaguardar. Esta é a tarefa própria da liberdade - por não dizer, a sua verdade - a ser cumprida historicamente na construção da morada humana sobre esta terra. (HEIDEGGER, 2004e, p. 143) Tantas vezes, porém, é realizada em modos deficientes.

No âmbito da Verborgenheit, porém, como se ressalta na conferência supracitada, reside a possibilidade de algo radical em relação a este privilégio e preponderância, principalmente quando o habitar humano e o construir do mundo humano tem sido a errância de uma afeição de tudo objetivar, assegurar e controlar, (HEIDEGGER, 2006d, p. 158) degradando, desde o cerne, a dignidade humana, que "está em guardar, nesta terra, o descobrimento e, com ele, já, cada vez antes, o encobrimento". (HEIDEGGER, 2004a, p. 36; tr. por., p. 34) Esta radical possibilidade é a de experienciar o oculto do fundamento de nossa própria existência e, nisso, consumar um saber originário acerca da essência mais originária da verdade. (HEIDEGGER, 2004g, p. 187, 194) Trata-se de uma experiência ainda inusitada para a história do Ocidente, já que essa essência da verdade é o chão ainda não habitado, o solo intacto de nossa ek-sistência e liberdade, por não ter sido ainda sondado pela metafísica. Na verdade, a metafísica deslocou este chão para uma existência centrada em si e fundada por si mesma e abandonou o solo da origem ao seu velamento. Deste modo, o chão está antropologicamente concebido, na medida em que o homem, desde a modernidade, se tem como fundamento, derradeiro e inabalável - de si, de tudo o que é, como também de todas os seus comportamentos e relações com o que é. (HEIDEGGER, 1998, p. 126; 2003b, p. 93, 109, 111-112) A fundação da existência do homem no solo intacto da origem, para dele se erguer como ser-livre, então, pressupõe a já assinalada transformação da essência metafísica do ser humano como animal rationale. "Pois a verdade como a clareira para o encobrir-se é o fundamento para o ser do homem - algo diverso do que nós mesmos somos e ao que nós, no entanto, pertencemos, ao que precisamos pertencer se quisermos saber originariamente a verdade". (HEIDEGGER, 1992, p. 2012; tr. por., p. 268)

Sobre abrir fendas, cravar o chão da existêncía: verdade e liberdade no pensamento tardio de Heidegger 


\section{Aoristo)))))}

\section{International Journal of Phenomenology, Hermeneutics and Metaphysics}

Os homens chegarão a realizar a verdade da sua liberdade se forem, antes, deslocados para o fundamento de sua existência histórica. Como ek-sistentes, se eles ainda não pertencem a este chão, a história da metafísica é de uma prolongada falta de experiência da clareira, do livre da verdade do ser, em especial, do ocultamento que nela impera. Já não sabemos guardar o encobrimento. Habitualmente, pela razão da inexperiência histórica com este fundamento oculto da existência humana enquanto clareira para o mistério da verdade, também a liberdade humana é concebida antropológico-subjetivamente. Como nos mostrou Kant (1974, p. 59), a liberdade é a condição em que o homem, estabelecida por ele mesmo ao manter a reta ordenação de suas faculdades segundo os diferentes interesses de sua razão, solta-se dos grilhões das representações dos objetos externos e materiais, para vincular-se a uma obrigação, isto é, a uma representação imposta a si de modo autônomo (respeito à lei moral) ${ }^{9}$. Deste modo, no fim, a verdade da liberdade seria obedecer a si mesmo, cuidar e custodiar apenas de si mesmo, o que é garantido pela certeza e asseguração da própria essência, ao momento que o homem se representa como ente racional e pela razão estabelece as leis de uma vontade livre. E isto é possível desde que a nova liberdade dos modernos é o liberar do homem para se determinar em sua essência, exclusivamente por meio de si, então, sem recorrer a nenhuma determinação ou compreensão prévia da tradição. (HEIDEGGER, 1998, p. 126; 2003b, p. 107, 109) Livre, portanto, é o indivíduo que assume sob si os encargos de ser o sujeito da própria liberdade, exigência experimentada como uma condição imperativa e inalienável. Na perspectiva da história do ser, porém, o homem poderá, de fato, custodiar o seu modo próprio de realizar-se, se toma sob a seus cuidados não apenas os requisitos de sua autonomia, mas primordialmente a tarefa de sustentar o livre da verdade do ser: "enquanto ek-sistente, o homem sustenta o Da-sein, na medida que toma a seus 'cuidados' o aí $(D a)$ como clareira do ser". (HEIDEGGER, 2004h, p. 327; tr. por., p.340) O homem será livre, consoante a verdade de sua estrutura fundamental e liberdade que nela se instaura, se sua ek-sistência for a abertura em que o fundamento é preservado como tal. Ora, subjectum possui o significado de fundamento, tanto no sentido etimológico quanto metafísico; segundo a compreensão da modernidade, porém, nomeia a disposição do homem de pôr-se, como o fruto da liberdade para se determinar, como o solo seguro e certo de todo ente. Neste sentido, para a superação desta experiência autofundante do homem na sua liberdade, a obrigação categórica seria que o homem, em seu modo de ser, passasse a vigorar na audiência de uma profunda ocultação da verdade, mediante

\footnotetext{
${ }^{9}$ Veja também a esclarecedora nota de Kant (1974, p. 27-8, segunda nota), em Grundlegung zur Metaphysik der Siten. Chamamos atenção que por respeito à lei, Kant utiliza o termo Achtung, que possui também o significado de atentar, mas também cuidar e custodiar. Nesta perspectiva desta liberdade, respeito à lei significa que o homem cuida do seu modo próprio de ser enquanto um ente autônomo e que tem o fim em si mesmo. No entanto, este cuidar e custodiar essa possibilidade mais própria de ser, segundo a compreensão moderna, por estar fundada no sujeito, ainda não alcançou a radicalidade da liberdade e o fundamento originário da existência humana, na medida em que ainda não é o Da-sein do mistério da verdade.
} 


\section{Aoristo)))))}

International Journal of Phenomenology, Hermeneutics and Metaphysics

cordial e obediente correspondência ao fundamento oculto de sua existência. Seria o verdadeiro imperativo, então, que sua existência ressoasse o apelo para outra destinação da história, a convocação de outra liberdade, mesmo que, de início, isto se faça a custo de um abalo desta posição antropocêntrica de fundação da própria existência, um choque no fundamento que até então tem sido tido como inconcusso. Para tanto, o apelo não deverá ser relativo a objetos, ideias, representações, mas sim provir de uma extrema necessidade, nascida da percepção da carência do fundamento da verdade do ser. E se a liberdade humana se vincula com o acolhimento de uma necessitação (Nötigung) da qual não se escapa em nossa cotidiana existência, o que Kant (1974, p.126) já assinalava, a virada para esta necessidade, anterior à qualquer regra formal-objetiva e típica de uma essencial indigência, estaria a possibilidade para a outra liberdade e essência humanas, não metafisicamente realizadas.

No sentido desta superação está ordenado o esforço de pensar a essência humana como ek-sistência ao reconduzir a essência da liberdade humana para o êxtase (o ek-) da abertura, o arroubo transcendental da existência. Assim, por certo, a expressão lapidar da conferência de 30 , "A essência da verdade é a liberdade", (HEIDEGGER, 2004g, p. 186; tr. por., p.198) de modo concentrado, define a verdade da liberdade humana e aponta para o complexo de questões apontadas nos parágrafos precedentes. Se considerado o inteiro desenrolamento da elaboração da questão desta conferência, bem como o desdobramento do pensamento que nela se intenta pela primeira vez, é dado afirmar que se trata de uma afirmação na qual se deve apreender um constante movimento de passagem do desvelamento para o ocultamento, como também do ocultamento para o desvelamento, na unidade de único movimento. Nela se espelha o jogo da liberdade que, em nossos temos, é passagem contínua, simultânea e recíproca da verdade da liberdade para a liberdade da verdade. No primeiro nível de compreensão deste jogo, aquele em que o desvelamento é colocado em primeiro plano e a liberdade é situado no âmbito da $e k$ sistência, claro, sem perder de vista a necessidade de reconduzi-la ao apoio oculto do fundamento, é paradigmática a seguinte afirmação: "A liberdade em face do que se manifesta no interior do aberto deixa que cada ente seja o ente que ele é. A liberdade revela-se, então, como o que deixa-ser (Sein-lassen) o ente". (HEIDEGGER, 2004g, p. 188; tr. por., p. 200) Por sua vez, no segundo plano, que coloca a orientação da passagem no ocultamento da verdade e devolve a liberdade para o fundamento, sem esquecer que este precisa ser sustentado pelo deixa-ser da ek-sistência transcendental, poderia ser, entre outras, a seguinte: "O homem não possui a liberdade como uma propriedade, mas antes, vale o contrário: a liberdade, o $D a$-sein ek-sistente e desvelador, possui o homem; e isto tão originariamente que somente ela permite a uma humanidade inaugurar a relação com o ente na totalidade e enquanto tal, que fundamenta e distingue toda a história". (HEIDEGGER, 2004g, p. 190; tr. por., 202) Segundo esta última direção, então, o desvelamento, a $\dot{\alpha} \lambda \eta \dot{\eta} \theta \varepsilon \iota \alpha$, não é feito do homem nem produto da sua liberdade ek-sistencial. Ao contrário, na $\dot{\alpha} \lambda \eta \dot{\theta} \theta \varepsilon ı \alpha$,

Sobre abrirfendas, cravar o chão da existêncía: verdade e liberdade no pensamento tardio de Heidegger 


\section{Aoristo)))))}

\section{International Journal of Phenomenology, Hermeneutics and Metaphysics}

enquanto clareira oculta da verdade do ser, encontra-se fundada a essência do homem. Portanto, da sua luz depende o exercício apofântico do $\lambda$ ó $\gamma$ os (HEIDEGGER, 2013, p. 27, 33) que, desde os primórdios da metafísica, inscreve-se na definição do ser humano, determinando-o como sendo o único ente que libera o seu mundo em formas múltiplas de discursá-lo. Então, a verdade da sua liberdade, em seu poder de deixar-ser, é apenas o reflexo e a sombra da luz da liberdade que inaugura os desvelamentos da totalidade do ente ao longo das épocas.

Ora, se a liberdade é tão originária, a tal ponto de tomar o homem por inteiro, no Da-sein ou na sua estrutura profunda e fundamental e responsabilizá-lo por sustentar os diversos modos de levantes epocais do ente no seu todo, a quem pertence propriamente esta liberdade? A resposta é: ao ocultar do ocultamento, ao aprofundar do fundamento que se oculta. É que, ao se retirar, o fundamento deixa o homem ser. Em que medida? Enquanto cria o "nada" e, com isto, deixa eclodir a "condição de possibilidade" do modo de ser do homem enquanto ek-sistência: o livre da aberta. Ao dar sustentação tempo-espacial a esta aberta, na ek-sistência do homem age na sua finita liberdade. De outro modo, o livre da aberta possibilita-o a realizarse como ser-livre. Contudo, por a abertura se dar como uma luz oculta, leve e liberadora, (HEIDEGGER, 2007b, p. 80-81) a proveniência desta possibilidade provém da aberta (Offenheit), é ela mesma, a qual Heidegger nomeia clareira para o ocultar-se (Lichtung für das Sichverbergen) de modo exaustivo nos Beiträge zur Philosophie. Deste modo, a clareira se manifesta como este livre iluminador e liberador, porque nela acontece o mistério da verdade, isto é, conquanto o ser, como origem e fundamento, vigore no abismar de um abismo. Por isto, a clareira do ser mesmo se mostra como o "fundamento" do fundamento. (HEIDEGGER, 1997, p. 101) $\mathrm{Na}$ verdade, aquela estrutura fundamental do homem, o Da-sein, está assentada na ocultação que resguarda o mistério. É este o fundamento primordial. No sentido primeiro, então, o fundamento não é a transcendência da ek-sistência, pela qual o $D a$ sein erige o mundo e toma chão e apoio no ente desvelado como tal ${ }^{10}$, mas sim o

\footnotetext{
${ }^{10}$ Heidegger (2004f, p. 165-70), em Wom Wesen des Grundes, mostra que a liberdade tem a ver com fundar. Contudo, no sentido de transcendência, realiza-se apenas um entre os sentidos de fundamento proporcionado pela liberdade, aquele que funda a verdade ôntica (o desvelamento dos entes no comportamento para com eles). Propriamente nessa direção movem-se as tentativas de fundar a noção da verdade como adequação na história da metafísica. Em consonância e em unidade com o fundar transcendental-ekstático ao modo de projeção do mundo (Begründen), o Dasein assume sua liberdade em fundando em dois outros sentidos, os quais conjuntamente permitem a compreensão do ser dos entes, mas não constituem um comportamento para com eles. São esses dois outros modos de fundar: (1) o erigir, instituir (Stifen), o principal entre os três e (2) tomar-chão (Boden-nehmen), apoiar-se ou assentar-se. O primeiro desses dois, tal como descrito em Sein und Zeit, é justamente aquele retornar do Dasein à sua possibilidade mais própria e querê-la vigorosamente por mor de si mesmo. Isso significa que o fundar como erigir não é outra coisa que o projeto do Dasein, experimentado na propriedade do ser em função de si. Contudo, enquanto possibilitador da transcendência, esse modo de fundar significa retrair-se diante do ente que não possui o modo de ser do Dasein, tensionando-se para si, para desvelar o todo do ente como o horizonte de projeção do mundo. Assim, em assumindo a si mesmo, está se referenciando ao todo, instituindo-o como o lugar de ereção do mundo concernente à sua possibilidade de ser. No projeto de mundo, porém, o ente como tal permaneceria velado, caso o Dasein não se assentasse nele, não fizesse dele o chão firme de sua existência. Como se dá isso? Em se projetando e abrindo o todo do mundo,
}

$$
\begin{aligned}
& \text { Daniel Rodrigues Ramos } \\
& \text { Toledo, v. 4, n*1 (2021) p. 105 141 }
\end{aligned}
$$


acontecimento pelo qual o desvelado como tal vem à tona: o acontecimento da verdade do ser como abismo (Abgrund). Por esta razão, a essência originária do fundamento (Urgrund) é o modo do ser se ausentar, de tal modo que o fundar do fundamento é uma forma deste último se subtrair e se retirar, ocultando-se nas profundezas da origem e dando a falsa aparência que o fundamento seja uma total falta de fundamentação (Ungrund). (HEIDEGGER, 2003c, p. 379-380) Porém, Abgrund, fundamento abissal, nomeia o modo originário de vigorar do fundamento, propiciar o fundo que, ao modo da retração da origem, deixa ser. Neste modo, o fundamento não tem a liberdade, mas é a liberdade em seu acontecimento mais misterioso em total poder liberador e gerador da história. Como tal, indica a criação de um fundo sem fundo, que faz recuar e revirar o chão mesmo da existência, impele o ek-sistir a lançar-se para dentro da fissura criada pela subtração abissal do fundamento, atraindo-a com a força de uma indigência para ali enraizar a finita liberdade dos homens históricos.

Por conseguinte, o recuar e ocultar-se do fundamento nada tira, no sentido negativo; não gera mera carência como falta. Se é privação, esta é no sentido de precisão, de uma necessidade que constringe e vincula o homem com o acontecimento que lhe concede a sua essência. Assim, ao contrário de uma privação que impede ter posse de algo ou si, o ocultar-se e a recusa libera o homem para se apropriar do seu fundamento enquanto $D a$-sein: insistência em ser a abertura tempoespacial, a transcendência ek-stática, em que o ser pode se mostrar em seu oculto desvelamento. Deste modo, convoca o homem a assumir o "lugar" onde se guarda e protege o mistério do ser, que ao retrair, deixa tudo ser. Mas o faz ao solicitar ao homem que seu modo de ser seja o conceder-se ao fundamento abissal e, ao mesmo tempo, cedência de um espaço e tempo para que o ente possa se manifestar naquilo que verdadeiramente é. Solicita-se ao homem que insista em fazer de sua existência um âmbito histórico de salvaguarda. Assim, por ser abrigo que doa ao homem a possibilidade de perfazer-se como abertura ou trans-cendência que protege a verdade do ente, cada um e no seu todo, a este fundamento abissal pertence, de

\footnotetext{
ele se dispõe no ente como tal, tornando-se susceptível a ele. A totalidade do ente toca-o mediante esse projetarse, que ultrapassa aquele. Por isso, tal projeto é afetivamente afinado ou entonado pelo ente em si mesmo. Assim, o Dasein pode transcender-se, se deixa ser tomado plenamente pelo ente como tal - aqui, descreve-se uma absorção (Eigenomenheit), um ser tomado pelo ente como tal, ao ponto de nele encontrar fundamento. Daí surge a possibilidade do Dasein ser um ente em meio aos entes, sem que seja um dos entes intramundanos, justamente em virtude de ter erigido e assentado sua transcendência na totalidade do ente. O mundo, que daí decorre e se extravasa, pode ser a fundamentação para a descoberta dos entes, somente enquanto o Dasein se autofunda como esse ente em meio ao ente nos dois últimos modos descritos. Na unidade dos três modos de fundar, o Dasein é livre. Porém, ao final da conferência, é asseverado em relação àquele primeiro sentido de fundar situado na ek-sistência transcendental: "O fundamento que, transcendendo, emerge remonta à própria liberdade, e essa, como origem, se transforma ela mesma em 'fundamento'. A liberdade é a razão do fundamento (o fundamento do fundamento). [...] Enquanto este fundamento, porém, a liberdade é o abismo (semfundamento, Ab-grund) do ser-aí”. (HEIDEGGER, 2004f, p. 174; tr. por., 187) Já no horizonte ek-stático transcendental, portanto, a liberdade inaugura o fundamento; é o acontecimento pelo qual este pode fundar. E nada a antecede. Deste modo, a liberdade é doação de fundo, de chão, simplesmente por doar. Donde provém esta doação enquanto puro acontecimento da liberalidade? Esta, porém, é a questão da verdade do ser, que a conferência apenas prepara.
}

Sobre abrirfendas, cravar o chão da existêncía: verdade e liberdade no pensamento tardio de Heidegger 


\title{
Aoristo)))))
}

\section{International Journal of Phenomenology, Hermeneutics and Metaphysics}

modo primordial, a liberdade. (HEIDEGGER, 2013, p. 27) Em Besinnung (1938/39), Heidegger (1997, p. 109; tr. por., p. 102) esclarece com a gramática do pensamento da história do ser: "A clareira da abertura ardente é a clareira do ser (Seyn), que silencia de maneira a-bissal a indigência do fundamento e se apropria em meio ao acontecimento da fundação do dizer com respeito à necessidade, uma necessidade que deixa emergir a liberdade como história no sentido de luta entre decisões essenciais". Aqui, no ato ou disposição humana de pôr a sua abertura descobridora como fundo para o abismo, no palco da histórica, está o acontecimento da doação da origem que, se acolhida, passa a imperar como a necessidade que vincula e cria, em cada época, a condição de possibilidade da liberdade humana.

Ao fundamento abissal, então, o homem, se quiser conquistar a sua liberdade, deve se entregar ou suportá-lo com a própria existência. Assim, "a liberdade é o abandono ao desvelamento do ente como tal", diz-se de modo suscinto na Wahrheitsvortrag. Ou também: "a ek-sistência enraizada na verdade como liberdade é a ex-posição ao caráter desvelado do ente como tal". (HEIDEGGER, 2004g, p. 189; tr. por., p.201) Deste modo, a existência não é somente ek-sistência. Ela é também e ao mesmo tempo in-sistência, (HEIDEGGER, 2004g, p. 193) justamente para poder enraizar-se no seu fundamento, cravar a existência no solo fendido pela ferida abissal. Porém, assim o homem é kehrig, isto é, girado, virado e revirado desde o mais íntimo de sua ek-sistência para o fundamento oculto, porque chamado de volta para o centro do movimento de recolhimento do abismo (HEIDEGGER, 2003c, p. 407) e decisões fundamentais da história. Nisto, o homem não é mais sub-jectum, fundamento inconcusso. Todavia, é fundado na liberdade da verdade, favorecido com finita possibilidade de ser-livre - acontecimento pelo qual pode dar-se a outro princípio da história do Ocidente e alavancado outro início da história da $\alpha \hat{\lambda} \eta \dot{\eta} \theta \varepsilon ı \alpha$.

Por conseguinte, considerada desde a estrutura profunda e fundamental do homem, a verdade da liberdade é o deixar-ser (Sein-lassen). Considerada a partir do fundamento abissal, também o é, porém, a partir de um acontecimento oculto que toma o homem como o dom de uma diretiva histórica, como o iluminar da luz que se oculta, convocando-o a insistir no seu modo mais próprio de ser, a saber, deixar tudo vigorar na origem generosa e retraída. Nesta última dimensão, a liberdade humana se revira, como ek-sistência insistente, na liberdade da verdade como que no retorno à pura vigência da liberalidade - plano fundamental onde o pensar e o agir não se referem a objetos, não são nada além que a ação de doação e recepção e, na unidade de ambos, Seyn-lassen, na ambiguidade entre genitivo objetivo e subjetivo não possível de ser extirpada. Para a liberdade dos homens, isto é fundar em vista do mistério que tudo pré-funda, o que pressupõe a decisão de dispor-se por uma desconhecida, imprevisível experiência de transformação do modo como a humanidade histórica consumou sua essência e, assim, como atualmente e há muito tempo deixa o ente ser e, certamente, desleixa de sua verdade. É bem provável que ainda estamos acostumados a liberar o ente, porém, mantendo-o preso na teia de nossas representações, incorporando-o em cadeias de dispositivos acessíveis aos

\author{
Daniel Rodrigues Ramos \\ Toledo, v. 4, n*1 (2021) p. 105 141
}




\section{Aoristo)))))}

International Journal of Phenomenology, Hermeneutics and Metaphysics

mecanismos de exploração, processamentos ilimitados e o domínio global da produção em massa. Então, é uma questão preliminar da verdade de nossa atual liberdade, se, no mundo dos processos técnicos e mediante os comportamentos científicos e pragmáticos, o ente é liberado como e o que ele é. Por esta razão, até o momento, podem ser tomadas como conclusivas as seguintes palavras da obra Besinunng:

O deixar-ser do ente como e o que ele é. Acha-se que se alcança algo assim da forma mais pura possível por meio da indiferença, do não fazer nada para tanto e do não retirar nada daí. Mas o deixar-ser pressupõe inversamente a insistência mais elevada na verdade da essência do ser (Seyn). Insistência como persistência íntima na fundação da verdade do ser (Seyn), para cuja fundação o homem é indicado quanto mais essencialmente sua essência é arrancada da animalidade e da espiritualidade. (HEIDEGGER, 1997, p. 103; tr. por., p. 99)

Como o homem reafirma sua liberdade e realiza o deixar-ser desde a essência do ser enquanto fundamento do fundamento, então, desde a primitiva, abissal e inesgotável liberalidade da verdade?

\subsection{A LIBERDADE DA VERDADE. A LIBERDADE INAUGURAL}

Acima, no primeiro momento, a liberdade, enquanto deixar-ser (Sein-lassen), apareceu como a essência da verdade. Essência é o dinamismo e acontecimento de vigorar. Neste sentido, a verdade é o vigorar de uma aberta que deixa o ente no seu todo mostrar-se, cada vez, naquilo que ele é. A aberta do ser, então, deve ser entendida ontologicamente como livre que concede a cada ente fazer-se e manter-se patente. Assim, a verdade libera para que o ente seja; a verdade, enquanto vigência de uma aberta, é libertadora, porque entrega o ente a ele mesmo. No seio da abertura desta aberta, no cerne da liberdade deste livre infinitesimal, encontra-se o homem, de tal modo que por meio dela também ele é entregue a si mesmo. Porém, ele o é de um modo especial, à medida que a verdade, por meio da aberta, responsabiliza-o por manter vigorosa esta liberação da liberdade, vinculando-o com esta manifestação do ente no seu todo. Então, do ponto de vista da essência do homem, no movimento de sua transcendência, isto é, atentando apenas para a estrutura fundamental do serhomem e compreendendo-a como uma singular tarefa da liberdade, a verdade é expor-se ao ente e favorecer que tudo seja patente. Numa só palavra: ek-sistente. Já nesta dimensão, na face manifesta da verdade, a liberdade é, para o homem, o empenho insistente de transcender e continuamente se constituir como renovada abertura a partir da verdade; é o seu exclusivo inter-esse. Para uma visualização mais concreta desta condição do homem como tarefa de ter que ek-sistir na verdade, de sustentar um "entre" - sempre histórico, por sinal - em que todos os entes se manifestam, eis um exemplo:

Sobre abrirfendas, cravar o chão da existêncía: verdade e liberdade no pensamento tardio de Heidegger 


\section{Aoristo)))))}

International Journal of Phenomenology, Hermeneutics and Metaphysics

Tomemos um exemplo da coragem. Coragem não é coisa que você adquire como objeto já existente diante de você. A coragem é uma abertura, um modo de ser no qual você tomando todo o seu ser deve entrar. Mas esse entrar não é um entrar no 'espaço' já existente. É uma abrir-se e manter-se renovando-se sempre de novo nessa abertura. Aqui surge a estrutura que poderíamos concretizar como contínua auto-assumpção, renovação contínua, na qual cada passo que você dá deve reassumir todo o seu ser passado e se expor de novo à abertura da coragem que se tornando cada vez mais nítida, que vai se desvelando no que ela é; e ao se revelar exige por sua vez o engajamento renovado e potenciado. É o transcender-se a si mesmo, a auto-superação. É nesse movimento dinâmico que vai se constituindo cada vez mais plástica e nitidamente o eu-coragem ou eu corajoso e esse eu-corajoso é uma espécie de ocular que me faz ver ao meu redor todo um mundo de valores de coragem. (HARADA, 1970, p. 30)

Em síntese, é em função de seu caráter descobridor que a verdade é (vige como) liberdade. Em consonância a esta dimensão reveladora, a humana liberdade vigora como decisão de sustentar a ek-sistência como a abertura que se expõe ao ente, aliás, como cuidado e favorecimento de seu desvelamento. Não ao modo de um poder de controle planetário. Contudo, pouco a pouco, à medida que se acentuou que a verdade pertence ao ser mesmo e o não-desvelamento se tornou o caráter diretivo do acontecimento da verdade, o dar-se liberador da verdade se mostrou como o fundamento que se recusa abissalmente. Neste sentido, a abertura primordial já não é a temporalidade-espacialidade que se desdobra e consuma o modo de ser (-sein) do homem como o $D a$ - do mistério do ser em seu recolhimento e, concomitante, o "aí" que suporta a manifestação de todos os entes. A liberdade não se dá unicamente enquanto estrutura fundamental do ser-homem, mas, sobretudo, enquanto o acontecimento fundamental desta estrutura, pensada desde uma doação primigênia, tão antiga quanto a história da humanidade. Este acontecimento é mais imperioso que a constante renovação da abertura da ek-sistência. Deste modo, a abertura iluminadora deste oculto acontecimento, a verdade do ser, é prévia a este fundamento ek-sistencial; é o 'fundamento' deste fundamento, melhor, o sem-fundo do fundamento abissal. Neste, toma chão o abrir-se histórico e singular do humano.

Portanto, a liberdade pertence ao dar-se retirante do ser, vigora neste e a partir deste acontecimento, pelo qual a verdade em seu caráter desvelante é protegida e guardada. Se a aberta também pertence ao ser em seu mistério, a liberdade precisa ser colhida desde a vigência de sua verdade, para a qual é essencial o recolhimento, as despedidas, o soltar-se, em síntese, o absconder do ser. Em toda ocultação (Verbergung), se originária, impera o absconder (Bergen, Bergung). O abscondido, porém, não é fundamentalmente aquilo que se afastou para seu esconderijo e tornouse inacessível. Sua essência é a custódia $(H u t)$, o pôr a salvo e seguro (HEIDEGGER,

$$
\begin{array}{r}
\text { Daniel Rodrigues Ramos } \\
\text { Toledo, v. 4, n*1 (2021) p. 105 141 }
\end{array}
$$


International Journal of Phenomenology, Hermeneutics and Metaphysics

2013, p. 12) e sua via de acesso é o amparo. Entre o absconder e a custódia há uma contradição apenas aparente. Assim como o deixar-ser não é uma indiferença, o ocultar-se do ser não é simples dissimular-se, mas sim, justamente enquanto acontecimento do abscôndito, um autêntico abandono do ente. No sentido usual, porém, abandonar é o deixar que relega ao desamparo; é um esconder que se desvia na mera indiferença. Contudo, em vez de tal menosprezo, o abandono é originariamente positivo, pois mostra-se como retiro do salto para trás que cuida para não se pôr e antepor ao que deve aparecer, por si e em si; assim, é movimento de retaguarda, de pôr-se em segredo com o fim que o abandonado seja entregue a si mesmo, no caso do humano, agraciado com a responsabilidade de ser o que pode ser. O pensar livre das variadas formas de antropocentrismos (dos preconceitos psicologistas, por exemplo) sabe que o abandono é um dom. E o homem que conforma a sua ek-sistência por meio deste pensar, toma o aparente, o que lhe foi entregue, em síntese, o verdadeiro tal como ele é: a doação de um dom. Por conseguinte, para entregar tudo ao homem na sua mais íntima "verdade", o ser necessita ocultar-se no abscôndito. E este absconder-se é, em última instância, o proteger-se que concede. Nesta concessão doa-se o ente, liberta-o, cuidando para que seja. Por esta razão, o absconder é a intimidade do deixar-ser. Deste modo, o "verdadeiro"11 da verdade (o Wahr da Wahr-heit) é a salvaguarda do cuidado que concede ao ente ser - por exemplo, em se ocultando, o ser outorga ao homem a estrutura fundamental na medida em que desdobra a sua verdade como desvelamento no primeiro sentido de clareira da ek-sistência transcendental $(D a)$. (HEIDEGGER, 2013, p. 52) Em resumo, o ser da verdade (então, desde a guinada da Kehre para o mais primitivo ocultamento iluminador, para o interior do acontecimento inaugural da história) é a vigência do abrigo protetor-concedente. (HEIDEGGER, 2013, p. 23) E conceder possui, aqui, o sentido de permitir desgarrar, deixar livre, porém, no mais seguro da essência daquilo que neste acontecimento é libertado.

\footnotetext{
${ }^{11}$ Verdadeiro não deve ser entendido a partir de seu significado lógico-proposicional. No mesmo movimento da Wahrheitsvortrag de retroagir o conceito de verdade como adequatio para o velamento do ente na totalidade, aqui se pensa a verdade a partir do Ereignis. Nesta perspectiva, verdadeiro é um conceito essencialmente ambíguo. De um lado, diz o desvelado, pensado a partir da sua vigência desde o princípio da metafísica como o levante da ólńqeia e, posteriormente, a luminosidade da íćc $\alpha$. Verdadeiro, nesta primeira acepção, diz muito mais o percebido, porém, não no sentido do que é empiricamente dado à sensação, mas sim como o que se doa e se conserva aberto na sua patência e, por isto, pode ser tomado como manifesto/verdadeiro. De outro lado, como se acentua acima, verdadeiro é a Bergung des Seyns, isto é, o seu absconder (HEIDEGGER, 2013, p. 52-53). O substantivo Bergung e o verbo bergen, porém, guardam um rico complexo de significados. Além do significado de abscondere, o verbo também denota servare (conservar, manter salvo, conceder), tueor (observar com o olhar, defender, proteger, cuidar), tegere (cobrir, recobrir, esconder, ocultar), celare (não deixar ver, manter escondido ou oculto). Cfr. Deutsches Wörterbuch von Jacob Grimm und Wilhelm Grimm, disponível http://dwb.uni-trier.de/de/. Consulta em: 21 jul. 2020. A ocultação pela qual o ser se encobre ou dissimula possui, portanto, o sentido de criar abrigo e manter a salvo neste abrigo que é a verdade.
}

Sobre abrirfendas, cravar o chão da existêncía: verdade e liberdade no pensamento tardio de Heidegger 


\title{
Aoristo)))))
}

International Journal of Phenomenology, Hermeneutics and Metaphysics

O abrigo, que cunha a verdade, impera como a iluminação de uma vasta aberta, paradoxalmente, desdobrada do ocultar. Diante deste acontecimento paradoxal, é preciso frisar que o ocultamento não é algo à parte do desvelamento, que o nãodesvelamento não é um fenômeno complementar, colateral; se assim fosse, seria certa deficiência do desvelamento. Pelo contrário, é a sua intimidade. Ora, é por graças do ocultamento, que a clareira se libera mais ampla, incomensurável em sua iluminação; revela-se abrigadora e protetora em sua expansão. Também, ao recolhê-la, o ocultamento faz da clareira uma pregnância esquecida, abandonada e até dissimulada, porém, é na invisibilidade de sua luz que ela tudo envolve e perpassa. Pelo desvelamento, por sua vez, a clareia do ser liberta sua profundeza, abre a sua insondabilidade. O ocultar do clareamento e o clareamento da ocultação são, em sua indissociável unidade, o núcleo vivo da vigência do ser que, como mistério, é sempre iluminação de sua própria recusa, retração, velamento, trancamento de si do seio da liberação. São ambos, na copertinência de claro e escuro, o único jogo e a íntima disputa do acontecimento da verdade com sua liberdade. Assim, a livre manifestação do ser, pela qual se doa ao ente e concede que este seja, traduz-se na hesitação entre velar-se e ocultar-se. Neste jogo hesitante, a liberdade é a vigência em que o ser se absconde, um movimento que, como atesta a língua latina, é o de fundar, instituir (condo,-ere), porém, por meio do afastamento, da ausência e da privação. Contudo, trata-se do afastar, ausentar-se ou privar que conserva no abrigo. Há liberdade, portanto, porque a verdade é amplidão abscôndita e abrigadora.

Por conseguinte, a liberação, que acontece no horizonte ek-sistencial da transcendência humana (a liberação do ser como Sein) está na mais profunda dependência do arquetípico acontecimento de constituição de sua clareira enquanto o movimento de uma guinada que retorna às profundezas da origem. Por "detrás" da liberação do ser - o que se indica como a verdade da liberdade - dá-se a liberdade da clareira do ser (enquanto Seyn, o acontecimento mais arcaico e enigmático), isto é, o evento primordial de doação e liberação de tudo o que é. Com efeito, em tudo que é verdadeiro, no vir à luz do todo, é patente o mistério da vida e do surgir que está por toda parte, de modo tênue, corriqueiro e quase banal. Porém, em todo este levante do ser (Sein) perdura um necessário descenso, tão cotidiano e omnipresente quanto este surgir e, por natureza, igualmente liberador. Pois no levante do ente no seu todo imerge a luz oculta da verdade do Seyn. Desta imersão, participa o homem, em sua liberdade; dela toma parte se a deixa ser em seu caráter abscôndito, na medida em que ama abismos do ser - isto é, procura-os, vigia-os e cuida em revelar sua profundidade insondável ao fundar o tempo-espaço da ek-sistência que guarda o mistério. No aparecer do Sein, então, como o nuclear de seu aparecimento, a liberdade oculta do Seyn reverte-se sobre si. Nesta via da Verwindung, isto é, da retorção do Seyn sobre si mesmo que sustenta todo o esquecimento nos desdobramentos das acepções de sua verdade ao longo da metafísica (a história da $\dot{\alpha} \lambda \dot{\eta} \theta \varepsilon 1 \alpha)$, o ser se rompe, cinde-se e diferencia-se de todo ente em sua entidade. Porém, é neste movimento que todo o ente é iluminado com a "indigência da

\author{
Daniel Rodrigues Ramos \\ Toledo, v. 4, n*1 (2021) p. 105 141
}




\section{Aoristo)))))}

\section{International Journal of Phenomenology, Hermeneutics and Metaphysics}

verdade e a originariedade da verdade". (HEIDEGGER, 2004c, p. 75; tr. por., p. 68) Esta originariedade é, pois, potência criadora, força principiadora da verdade (Anfängnis der Wahrheit) e, portanto, inauguradora de todo surgimento e vida.

Nesta reversão, o homem, entre os demais entes, é presenteado de modo especial com a despedida do ser, obsequiado com o descenso que torna possível o seu próprio levante. Pois, com isto, o vigor de seu modo de ser, isto é, sua finita liberdade enquanto deixar-ser é potenciada e, assim, e a clareira do $D a$ também pode se constituir como custódia $(\mathrm{Hut})$. Claro, se ele insistir em pertencer existencialmente ao dinamismo da Verwindung. Neste sentido derivado do primeiro, é do homem que a originária liberdade depende, porém permanece o sentido primeiro da verdade como amplidão abscôndita e abrigadora. Velar e proteger é também missão histórica do homem em sua ek-sistência transcendental enquanto tarefa de realização de sua essência e abertura do mundo histórico em obras e feitos capazes de traduzir e conservar a omnipresença do mistério do surgir e da vida. O segredo da vida ou da existência humana, em cada época, é ser sinal de uma doação que se despede (HEIDEGGER, 2004d, p. 130), assim, apropriar-se de uma antiga ausência que perpassa toda a história da humanidade, surgir como si mesmo no seio de uma inefável e inalienável desapropriação. "Somos um sinal, sem sentido", para relembrar os versos de Hölderlin. (2013, p. 303; tr. por., apud HEIDEGGER, 2004e/2002, p. 117) Em todo caso, este antiguíssimo movimento (retro)liberador da entidade e concessor da identidade ao ente obriga a dizer que "antes" da verdade da liberdade vigora, como o mais enigmático desta, a liberdade da verdade. Em base da sugestão de uma anotação de Heidegger (2013, p. 50), passamos a chamá-la de liberdade do princípio (anfüngliche Freiheit), porque nela se concentra todo dinamismo oculto e generativo da vida e do mundo histórico dos homens, em síntese, da história. Nela, preserva-se o segredo tanto do primeiro princípio (a história da metafísica ou do Ocidente), quanto daquele que poderá advir (o outro princípio). Trata-se, portanto, em bom português, da liberdade inaugural.

A liberdade inaugural indica e nos ensina que o mais patente é o sublimamente oculto, é aquilo que permanece invisível ao comportamento da transcendência humana exclusivamente focada no ente e, quiçá, no questionamento de sua entidade. De igual modo, ensina que o ser-livre, para ser na máxima potência de sua liberação, para se instituir como extrema liberalidade, necessita ser o trancamento da volta para o âmago do mistério; precisa ser a delicadeza de se impor e se ostentar no recolhimento. Como nos comportamos ou nos inserimos neste acontecimento em vista de constituir a nossa humana liberdade? Como absorvermos em nosso ímpeto de transcendência este ensinamento?

\subsection{A EXPERIÊNCIA DA LIBERDADE INAUGURAL: O FENDIMENTO DO CHÃO DA EXISTÊNCIA}

Como a vigência (da verdade), porém, atinge o homem no centro de sua eksistência? Enquanto permanece ela mesma é uma permanência junto ao homem.

Sobre abrir fendas, cravar o chão da existêncía: verdade e liberdade no pensamento tardio de Heidegger 


\title{
Aoristo)))))
}

\section{International Journal of Phenomenology, Hermeneutics and Metaphysics}

Porém, ela permanece como origem em sua força liberadora e criadora. Como tal, à medida que desdobra a sua vigência histórica, ela volta, cada vez mais fundo para si, para o seu abscôndito. Desse modo, a vigência gera a fratura da diferença ontológica pela qual se cindem homem e Seyn ou, na amplidão da totalidade de tudo que se levanta, a diferença entre Seyn e Sein. É por meio da instauração de um fosso (Kluft) no interstício entre o ente iluminado no seu todo, a vastidão da clareira, e o oculto abismo (HEIDEGGER, 1997, p. 99; 2013, p. 11) que se concede ao ente no seu todo que se levante. Mediante este acontecimento, instala-se uma fenda na ek-sistência do homem, pois a sua estrutura fundamental e profunda consiste em ser este interstício e sua transcendência é, desde sua interioridade, a insistência em ser este espaço temporal de sustentação desta cisão e concessão. Com seu poder inaugural e a "violência" criadora, portanto, a irrupção potente da liberdade do Seyn lhe fere a existência com uma cissura, deixa-lhe assinalado com o rasgo originário de sua verdade. Porém, a abertura deste ferimento não é senão o "salto para o interior do Seyn como acontecimento apropriador". (HEIDEGGER, 2003c, p. 278) Assim, tal abertura é inauguração da proteção e da guarda, por meio do ocultamento do Seyn, para que o homem venha a ser si mesmo segundo uma destinação epocal. Para o homem, permanecer junto à origem que o protege ao deixá-lo ser em sua essência história possui, então, semelhante ambiguidade entre dor e deleite de um sublime amor, pois, neste acontecimento da liberdade inaugural, ele também é ferido por um fosso abissal, pela intensa intimidade do ser mesmo. Suportar esta dor, ao permitir ao Da-sein vigorar como a ponte sobre aquele fosso, o elo intermédio entre o homem histórico e o Seyn, em resumo, o "lugar" em que transita o acontecimento de apropriação de ambos, é questão central da liberdade humana.

Insere-se na liberdade do ser, conquanto a transcendência ek-sistencial é a abertura de uma fissão subtil e, deste modo, o abrigo do abismal. Contudo, a tenuidade desta fenda é o acontecimento de um impacto imperioso, potentemente criativo, uma vez que faz a existência revirar do verdadeiro, do ente em suas múltiplas e variadas concreções, para a condição de já estar lançada na liberdade inaugural. E o giro se faz por meio de uma indigência da qual se não pode fugir, pois está em toda parte e em todo tempo. Nesta reviravolta para condição de já ser lançada em um âmbito inaugural e arcaico, a existência já não pode apoiar em ente algum, sabe-se suspensa no nada, que em nada mais se pode ancorar, a não ser no livre - que é o verdadeiro nada - desta liberdade. Se para a vigência do Seyn, o nada é o velamento da inesgotabilidade do abissal, a riqueza oculta do simples, para o homem é uma imposição radical; é constrição de uma necessidade sem par - pois, é a indigência fundada na ausência do que se retrai abissalmente. Mas nesta condição de indigente que o homem sabe-se solicitado, ao modo de uma obrigação ou incumbência inexorável, a deixar-ser. A indigência não é, então, a mera carência da privação, mas é originariamente o dom da possibilidade de se levantar de um chão fendido (a verdade do Seyn) a partir de uma necessidade ou de uma precisão infinita. Assim, esta especial e constringente privação é sein-lassend, a vigência de uma

\author{
Daniel Rodrigues Ramos \\ Toledo, v. 4, n'1 (2021) p. 105 141
}




\section{Aoristo)))))}

\section{International Journal of Phenomenology, Hermeneutics and Metaphysics}

liberação, porém, à medida que é uma voz que obriga ao homem a tornar-se quem é, isto é, a surgir e ressurgir renovadamente como a existência que deixa tudo ser. É dom da tarefa de insistir na própria abertura, potenciá-la desde a permanência junto à vigência da proteção de tudo que é. Portanto, é somente na necessidade experimentada por quem se virou para a indigência criada por um fundamento abissal que o homem pode se levantar (enquanto Da-sein) e pode acontecer a liberação de sua própria liberdade. (HEIDEGGER, 2013, p. 7) Deste modo, por meio da necessidade pressentida na indigência infinitesimal, o fendimento interpela ao homem o "espaço" em que o mistério do ser se mostra em sua profundeza. Ao mesmo tempo, solicita-lhe o espaço extasiado com a transcendência humana como o sítio em que todo ente pode ser reposto, recolhido no abrigo.

Por conseguinte, é por meio da abertura do fosso abissal (Zerfklüftung) que o homem é entoado em sua existência pela voz silenciosa do Seyn e convocado a não se arrebatar demasiada e unicamente em direção ao ente. Neste clamor provindo do abissal por meio do ferimento e do acometimento pela indigência do abandono do ser, a existência humana é despojada de sua pretensão de domínio do ente; o ser humano é conclamado de volta à experiência essencial de sua liberdade: “que nós, em sentido histórico, permaneçamos junto à essência/vigência (Wesen). Para tanto, é forçoso pela necessidade que nós renunciemos as interpelações estranhas e opulências; isto é o mais difícil em meio ao planetário (o mundo do progresso e do standard)". (HEIDEGGER, 2013, p. 59-60, tradução minha) Se esta experiência é despojo, ela não o é como mera espoliação das coisas que estão em sua posse, mas sim enquanto o livre retorno para o necessário, a virada para o âmbito originário que liberta e zela para que tudo repouse na sua essência. Ademais, nesta essencial referência ao Seyn e íntima conveniência com a liberdade inaugural, o homem é rico em propriedade, no sentido de pertencer ao seu próprio: não é privado de nada, mas transborda profusamente em e como Si-mesmo. (HEIDEGGER, 1994b, p. 8, 9) O caminho contrário a esta pobreza essencial enquanto riqueza do pertencimento à superabundância do Seyn, que é nada, é o da opulência. Ora, esta é o fruto do arrebatamento extasiante para o ente e nada mais; é a destinação histórica que pretende lograr, ser bem aventurada no apoderamento e empoderamento enquanto vontade de asseguramento. Como tal, é movida pelo poder, cujo dinamismo interno é a autoconservação no ter-se em contínua ascensão de sempre poder mais ter e, assim, ser capaz de transformar o ente por toda a parte. (HEIDEGGER, 2003c, p. 282) Opulência, então, é o poder violento que tudo transforma, mas não cria o homem histórico, pois não o despoja, isto é, não o faz saltar para dentro de sua possibilidade mais própria, para dentro do fosso abissal da origem. Por isto, é poder capaz apenas de desertificar a terra: sua (in)essência é incapacidade de dar-lhe sentido ou elevar o homem, acima de si mesmo, como o sentido da terra, como apontou Nietzsche (2011, p. 12) ${ }^{12}$. Para isto precisaria antes enraizar a existência no chão que é o fundo fendido.

\footnotetext{
${ }^{12}$ Para compreender a posição de Heidegger, talvez tenhamos que inverter o dito de Nietzsche, não para refuta-lo, mas para pensar a fundo o anúncio do Übermensch: que a terra seja o sentido do homem. Por isto,
}

Sobre abrirfendas, cravar o chão da existêncía: verdade e liberdade no pensamento tardio de Heidegger 


\title{
Aoristo)))))
}

\section{International Journal of Phenomenology, Hermeneutics and Metaphysics}

Incapaz de sentido, então, tal poder é impotente para curar a ferida originária - pois curá-la é guardá-la, dar espaço e tempo para que apareça o incalculável do acontecimento de mútua apropriação que nela se vela.

Certamente, por muito tempo o homem errou pelos caminhos deste poder. Trilhando-os, a humanidade chegou à condição em que tudo se tornou só vazio, pois, os descaminhos para a opulência conduziram o homem exclusivamente para o ente e para sua manipulação e domínio gigantesco. Entretanto, neste tempo, quando se consolidou a abertura da sua existência como violência desmedida, pela primeira vez, o homem é estremecido pelo fendilhamento do abissal. E começa a pressentir a inesgotabilidade do ser. (HEIDEGGER, 2003c, p. 244) Somente então, pulsa de novo, em meio à dor do abandono do ser e ao ardor suscitado pela intimidade com seu acontecimento velado, por meio desta ferida, a possibilidade do desmascaramento da ilusão ou equívoco que o vazio é raso, é mera falta de preenchimento. Nisto, o que verdadeiramente pulsa é a possibilidade do homem se elevar com seu mundo histórico desde sua essência mais originária e se transformar desde o núcleo de sua liberdade: deixar tudo ser, surgir desde um mistério ou profundeza abissal. É uma pulsão de liberdade, tendência pulsante de autoliberação. Porém, esta pulsão guarda no seu íntimo uma inalienável (inter)dependência; se tomado o homem desde suas raízes, toda pulsão de vida é também de morte. Porque é sobre os precipícios do Seyn que o homem se eleva como ser livre e ali tudo deve também se recolher, cerrarse, finar-se no infinito. De outro modo, em sua pulsão de liberdade, que envolve tanto a vida e a morte do homem, que se dá o levante de si em sua transcendência, desde que se saiba ser dependente da fundação da sua existência nos abismos do Seyn, agraciado com a liberdade da origem, o que é o mesmo dispor a sustentá-la no Da-sein. Nesta experiência da liberdade da verdade, a estrutura fundamental do homem se torna o que originariamente é: o apoio, o suporte fascinante, o sítio em que

\footnotetext{
“Exorto-vos, ó meus irmãos, a permanecerdes fiéis à terra”. (NIETZSCHE, 2017, p. 19) É da terra, pois, que brota a força da vida, a nutrição de todo surgir, o ímpeto dos levantes. Ela é um poder oculto. Contudo, terra não pode ser entendida como lugar geográfico, quinhão, pátria, astro, planeta, nem metafisicamente, a saber, como reino do devir e da história, em oposição ao reino das ideias, as únicas coisas capazes de perdurarem eternamente. Terra é, antes, o suporte que se encobre e ama se encobrir, oferecendo aos homens o chão do sentido de seu habitar, isto é, o assento do qual irrompe o mundo histórico dos homens. “Mundo e terra são essencialmente distintos e, no entanto, nunca são separados. O mundo funda-se na terra e a terra irrompe do mundo". (HEIDEGGER, 2003a, p. 35; tr. por, p. 47) Terra, portanto, é outro nome para o fundamento abissal, a abertura onde o fosso abissal imerge nas suas profundezas, é a clareira velada ou a proteção clareadora em que se decide por longas vias os destinos da história e dos povos. Sobre a terra, esquecendo de sua força generativa e inaugural e maltratando-a, o homem moderno construiu seu mundo: um conjunto de relações e interrelações que tem no processar e no incessante reprocessar os recursos naturais o fim calculado. $O$ produto deste cálculo, porém, sempre volta a ser meio para um processamento mais amplamente exploratório. No mundo dos modernos, tudo que é sobre a terra, inclusive os homens e os demais viventes, vige como dispositivo para os mecanismos de reprocessamento e exploratórios, cujo princípio é a objetivação da terra com recurso natural e energético. Deste modo, sem nenhum pressentimento do mistério que a terra protege, é que o homem expressa o poder violento da opulência, transformando tudo como objeto de um senhorio imenso, com dimensões planetárias. Mediante tal poder, o homem jamais será fiel à terra; será definitivamente incapaz de dar-Ihe sentido.
}

\author{
Daniel Rodrigues Ramos \\ Toledo, v. 4, n'1 (2021) p. 105 141
}




\section{Aoristo)))))}

\section{International Journal of Phenomenology, Hermeneutics and Metaphysics}

a verdade de tudo é recolhimento e união, vida e morte, surgimento e declínio, serena aquietação e levante. Se a humanidade em curso decidirá cravar a sua existência no fundo sem fundo do fosso abissal, portanto, não é uma questão acessória da liberdade humana, mas aquela mais digna de ser pensada.

De tudo isto se desprende que a liberdade não pode ser pensada como completa ausência de condicionamentos externos da ação nem como adesão à condição determinada por uma lei a priori da razão, então, deduzida de um princípio puramente formal e universalmente obrigante. Tudo isto é por demais indiferente ao modo como o homem se levanta e se liberta nas relações como os demais entes e, sobretudo, com o ser. Nesta indiferença, não se atém que a liberdade humana deve dizer algo de essencial a respeito da condição de ser projeto de si mesmo, de singularizar-se, consumado, porém, mediante à pertinência ao lance que envia cada homem histórico em singular, tanto os que vieram antes de nós, como também os nossos contemporâneos e os futuros. Aqui não são permitidos nem o aniquilamento da pertinência à humanidade histórica como também não a apatia ao envio que move a histórica em cada época, situações errantes das quais nenhum homem está ileso, mas de cuja assunção o homem se solta, libera-se, individua-se às custas de nelas lançar profundas raízes. Se o homem é lugar de passagem, o "onde" e o "quando", a ocasião e sítio no qual se abrigam a vida e a morte, o surgimento e o declínio de tudo que é, o passado e futuro ligados no intermédio da história presente, ele não pertence somente a si mesmo, mas ao todo oculto; o homem, em sua existência e liberdade, é apenas o meio pelo qual o ente na totalidade vem à fala e, assim, manifesta-se historicamente como discurso. Deste modo, a consciência da liberdade e sua reflexão devem partir de condicionamentos ainda não pensados justamente em sua força libertadora e criadora e isto em razão do seguinte princípio: "o deixar-ser pressupõe inversamente [às múltiplas formas de indiferença] a insistência mais elevada na verdade da essência do seer (Seyn)". (HEIDEEGGER, 1997, p. 103; tr. por, p. 99) Nossa humana liberdade pressupõe a inaugural e o nobre deixar sê-la em sua força criativa. Por isto, a essência da liberdade está na decisão livre de ser para o livre inaudito ou pertencer ao seu acontecimento, o que é deixar ser dominado por sua necessidade - algo que de uma forma ou outra sempre realizamos.

No âmbito da liberdade, então, o que é incondicionado é pertencer a esta originária condição. Deste modo, falham todas as superficiais divisões que a metafísica conservou de modo enrijecido em termos de modalidades e categorias ao imprimir ao ser o que vale apenas ao ente e ao agere ôntico: dúnamis e żnćrgeia, actus e potentia, essentia e existentia, em síntese, a dualidade entre possibilidade (possibilitas) e realidade (actualitas), a qual se desdobra em necessidade e liberdade ${ }^{13}$. Falha inclusive a preparatória ontologia fundamental que, ao tentar superar esta dualidade, ainda não pensa abissalmente a unidade do (necessário) estar-lançado e do (livre)

${ }^{13}$ Cfr. nota 7.

Sobre abrirfendas, cravar o chão da existêncía: verdade e liberdade no pensamento tardio de Heidegger 


\section{Aoristo)))))}

\section{International Journal of Phenomenology, Hermeneutics and Metaphysics}

poder-ser na própria realidade-possibilidade singular ${ }^{14}$ : o livre e o necessário são ainda experimentados como estruturas fundamentais do ser homem, são existencialidades humanas. É sem o solo da metafísica, sem o apoio de seus conceitos, mas tão somente no salto na escuridão do abismo que sustenta suas noções fundamentais e seus desdobramentos históricos a questão da liberdade pode avançar. Se o esquema metafísico ainda pode dizer algo sobre a essência da liberdade, a partir da duplicidade de significados de seu conceito, em sentido negativo ("liberdade de"), esta é liberação das falsas interpelações. Em sentido positivo ("liberdade para"), porém, ela é a liberalidade de uma pobreza essencial que se rejubila em virar-se e ofertar-se inteiramente para a necessidade que liberta os homens e todas as coisas. Contudo, é isto que abre a chaga da questão sobre o sentido de nossa existência. Em primeiro lugar, porque esta ambiguidade despertanos do nosso sono dogmático para pensar que ser homem é ser assenhorado por um poder gerador e instaurador, o qual, por ser ainda desconhecido e não experimentado na sua proveniência, é aferroador, aterrador, que coloca-nos por terra em todo empreendimento histórico de levantarmo-nos e, de modo aliado, elevar e edificar nosso mundo. Um poder, portanto, que nos devolve ao chão-fosso abissal de nossa existência e nos interpela, sobretudo, nas vicissitudes da história e dos indivíduos. Por isso, é por demais estranho, senão amedrontador, terrificante. Em segundo lugar, o apelo histórico emanado da dominação por este poder, enquanto decisão nuclear da liberdade, para que se torne um grande e alargado amor. Pois, mediante tal poder, somos lançados de volta à terra de toda a história, ao inaugural que já nos antecede muito antes e nos antecipa muito depois. A esta condição temos benevolentemente de ir ao encontro, embora nela há muito tempo já estejamos situados. Precisamos, porém, ainda sentir a necessidade de amar esta situação tão ampla e longamente condicionante, saltar insistentemente em seu mistério. Como expressão deste amor, a luta corpo a corpo com esta condição de estarmos lançados no acontecimento da verdade que em muito e há tanto nos precede, certamente, é algo digno de ser pensado e realizado neste tempo de desenraizamento de nossa existência do solo de nossa liberação. E isto para que nele se abra uma fenda. Este amor que prepara o porvir, então, é: medir-se com o nada (aquele que tudo dimensiona e abriga) em tom contido, porém, de modo generoso. Nada além disto parece ser mais essencial na tarefa da liberdade para atual humanidade. Neste amor, quiçá ser-nos-á ainda possível refazer historicamente a experiência do poeta:

\footnotetext{
${ }^{14} \mathrm{E}$, no entanto, a reta avaliação do passo dado com o pensamento de Sein und Zeit rumo à superação da metafisica necessita da escuta da interpretação de seu autor acerca do seu itinerário, implícita, por exemplo, nas seguintes afirmações: “Com o aceno para o que de que ser é compreendido como presentidade constante (beständige Anwesenheit), não demos nenhuma resposta para a questão diretriz, mas colocamos a pergunta diante do abismo de sua questionabilidade. E como o chamado de "ser e tempo", ousamos o salto nesse abismo e avançamos agora sem solo e sem apoio na escuridão". (HEIDEGGER, 1994a, p. 115; tr. por., p. 141) Para uma explícita tematização desta passagem da questão diretriz para a fundamental, que em Sein und Zeit já se tentava e encaminha o pensamento da $A b$-grund da questionabilidade, remetemos o leitor para a meditação 42 dos Beiträge zur Philosophie. (HEIDEGGER, 2003c)
}

$$
\begin{aligned}
& \text { Daniel Rodrigues Ramos } \\
& \text { Toledo, v. 4, n'1 (2021) p. 105 141 }
\end{aligned}
$$




\section{Aoristo)))))}

International Journal of Phenomenology, Hermeneutics and Metaphysics

E, de repente, nesse penoso "nada", de repente a estância inefável, em que a pura insuficiência se transforma -, e se torna abundância vazia,

onde a conta de muitas casas se resolve sem números.

(RILKE, 2005, p. 169)

\section{REFERÊNCIAS}

AQUINO, T. Suma teológica. Tomo I. Madrid: Editoral Catolica, 1957

ARISTÓTELES. Ética a Nicômaco. São Paulo: Atlas, 2009.

BUARQUE, C.; NASCIMENTO, M. Levantados do Chão. Rio de Janeiro: Marola Edições Musicais, 1997. Disponível em www.chicobuarque.com.br. Acesso em 17 ago. 2020.

CARNEIRO LEÃO, E. O último Heidegger. Ereignis por Parousia. Organização de R. Pizzolante. Rio de Janeiro: Universidade Federal do Rio de Janeiro, 2015.

FIGAL, G. Fenomenologia da liberdade. Rio de Janeiro: Forense Universitária, 2005.

HAAR, M. Heidegger e a essência do homem. Lisboa: Piaget, 1990.

HARADA, H. Verdade e liberdade. Seminário Da essência da verdade. 1970.

HÖLDERLIN, F. Gedichte. Berliner Ausgabe, 2013. Disponível em http://www.zeno.org. Acesso em: 13 ago 2020.

HEIDEGGER, M. Die Grundfragen der Philosophie. Ausgewählte »Probleme« der »logik«. Frankfurt: Vittorio Klostermann, 1992; tr. por., As questões fundamentais da filosofia. São Paulo: WMF Martins Fontes, 2017.

Vom Wesen der menschlichen Freiheit. Einleitung in die Philosophie. Frankfurt: Vittorio

Klostermann, 1994a; tr. por., A essência da liberdade humana. Introdução à filosofia. Rio de Janeiro: Via Verita, 2012.

Die Armut. In Heidegger Studien, 10, Berlin, 1994b, p. 5-11; tr. por. A pobreza. In

Phainomenon, Lisboa, 2012, p. 227-234. Disponível em: http://phainomenon-

journal.pt/index.php/phainomenon/article/view/320. Acesso em: 13 ago. 2020.

. Besinung. Frankfurt: Vittorio Klostermann, 1997; tr. por., Meditação. Petrópolis: Vozes, 2010.

Der Europäische Nihlismus. In HEIDEGGER, M. Nietzsche II. Frankfurt: Vittorio Klostermann,

1998. p. 23-229; tr. por., O niilismo europeu. In HEIDEGGER, M. Nietzsche II. Rio de Janeiro: Forense Universtiária, 2007. p. 21-193.

. Einführung in die Metaphysik. Tübingen: Max Niemeyer, 1998; tr. por., Introdução à

Metafísica. Rio de Janeiro: Tempo Brasileiro, 1999.

. Der Ursprung des Kunstwerkes. In HEIDEGGER, M. Holzwege. Frankfurt: Vittorio Klostermann,

2003a. p. 01-74; tr. por., A origem da obra de arte. In HEIDEGGER, M. Caminhos de floresta. Lisboa:

Gulbenkian, 1998. p. 5-94.

Die Zeit des Weltbildes. In HeIDEgGeR, M. Holzwege. Frankfurt: Vittorio Klostermann, 2003b. p.

75-113; tr. por., O tempo da imagem de mundo. In HEIDEGGER, M. Caminhos de floresta. Lisboa:

Gulbenkian, 1998. p. 95-138.

. Beiträge zur Philosophie (Vom Ereignis). Frankfurt: Vittorio Klostermann, 2003c; tr. por., Contribuições à filosofia. Rio de Janeiro: Via Verita, 2015.

Sobre abrir fendas, cravar o chão da existêncía: verdade e liberdade no pensamento tardio de Heidegger 


\section{Aoristo)))))}

International Journal of Phenomenology, Hermeneutics and Metaphysics

Die Frage nach Technik. In HeIDEgGer, M. Vortäge und Aufsätze. Stuttgart: Klett-Cotta, 2004a. p. 7-40; tr. por., A questão da técnica. In HEIDEGGER, M. Ensaios e conferências. Petrópolis: Vozes, 2001. p. 11-38.

Wissenschaft und Besinnung. In HeIDEGgER, M. Vortäge und Aufsätze. Stuttgart: Klett-Cotta, 2004b. p. 41-66; tr. por., Ciência e pensamento de sentido. In HEIDEGGER, M. Ensaios e conferências. Petrópolis: Vozes, 2001. p. 39-60.

. Überwindung der Metaphysik. In HeIDEGGER, M. Vortäge und Aufsätze. Stuttgart: Klett-Cotta, 2004c. p. 67-122; tr. por., A superação da metafísica. In HEIDEGGER, M. Ensaios e conferências. Petrópolis: Vozes, 2001. p. 61-110.

. Was heißt Denken? In HeIDEGGER, M. Vortäge und Aufsätze. Stuttgart: Klett-Cotta, 2004d. p.; tr. por. O que quer dizer pensar? In HeIDEGGER, M. Ensaios e conferências. Petrópolis: Vozes, 2001. p. 111-124.

Bauen Wohnen Denken. In HeIDEgGER, M. Vortäge und Aufsätze. Stuttgart: Klett-Cotta, 2004e. p.; tr. por.,. In HEIDEGGER, M. Ensaios e conferências. Petrópolis: Vozes, 2001. p. 125-141.

. Vom Wesen des Grundes. In HEIDEGGER, M. Wegmarken. Frankfurt: Vittorio Klostermann, 2004f. p. 123-175; tr. por., A essência do fundamento. In HEIDEGGER, M. Marcas do caminho. Petrópolis: Vozes, 2008. p. 134-188.

Vom Wesen der Wahrheit. In HeIDEgGER, M. Wegmarken. Frankfurt: Vittorio Klostermann, 2004g. p. 178-202; tr. por., A essência da verdade. In HEIDEGGER, M. Marcas do caminho. Petrópolis: Vozes, 2008. p. 189-214.

Brief über den Humanismus. In HEIDEGGER, M. Wegmarken. Frankfurt: Vittorio Klostermann,

2004h. p. 313-364; tr. por., Carta sobre o humanismo. In HEIDEGGER, M. Marcas do caminho.

Petrópolis: Vozes, 2008. p. 326-376.

Einleitung zu »Was ist Metaphysik?«. In HEIDEGGER, M. Wegmarken. Frankfurt: Vittorio

Klostermann, 2004i. p. 365-383; tr. por., Introdução à "O que é metafísica". In HEIDEGGER, M. Marcas do caminho. Petrópolis: Vozes, 2008. p. 377-395.

Sein und Zeit. Tübingen: Max Niemeyer, 2006a; tr. por., Ser e tempo. Petrópolis: Vozes, 2000.

HEIDEGGER, M. Ein Vorwort. Brief an Pater William J. Richardson. In HEIDEGGER, M. Identität und Diferenz. Frankfurt: Vittorio Klostermann, 2006c. p. 143-152.

. Brief an Takehiko Kojima. In HEIDEGGER, M. Identität und Diferenz. Frankfurt: Vittorio Klostermann, 2006d. p. 151-161; tr. por., Uma carta. In HEIDEGGER, M. O fim da filosofia ou a questão do pensamento. São Paulo: Duas Cidades, 1969. p. 13-19.

. Zeit und Sein. In HEIDEGGER, M. Zur Sache des Denkens. Frankfurt: Vittorio Klostermann, 2007a. p. 3-30; tr. por., Tempo e ser. In HEIDEGGER, M. Conferências e escritos filosóficos. São Paulo: Nova Cultural, 1999. p. 249-269. (Coleção Os Pensadores)

Das Ende der Philosophie und die Aufgabe. In HeIDEgGer, M. Zur Sache des Denkens. Frankfurt:

Vittorio Klostermann, 2007b. p. 67-90; tr. por., O fim da filosofia e a tarefa do pensamento. In Conferências e escritos filosóficos. São Paulo: Nova Cultural, 1999. p. 889-108. (Coleção Os Pensadores)

. Das Ereignis. Frankfurt: Vittorio Klostermann, 2009; tr. por., O acontecimento apropriativo. Rio de Janeiro: Gen, Forense Universitária, 2013.

. Zum Ereignis-Denken. Frankfurt: Vittorio Klostermann, 2013.

HUSSERL, E. Philosophie als strenge Wissenschaft. Hamburg: Meiner, 2009.

KANT, I. Kritik der praktischen Vernunft. Frankfurt: Shurkamp, 1974; tr. por., Crítica da razão prática.

São Paulo: Martins Fontes, 2003.

$$
\begin{array}{r}
\text { Daniel Rodrigues Ramos } \\
\text { Toledo, v. 4, n'1 (2021) p. 105-141 }
\end{array}
$$




\section{Aoristo)))))}

International Journal of Phenomenology, Hermeneutics and Metaphysics

Grundlegung zur Metaphysik der Sitten. Frankfurt: Shurkamp, 1974; tr. por., Fundamentação da metafísica dos costumes. Lisboa: Edições 70, 2005.

NIETZSCHE, F. A gaia ciência. São Paulo: Companhia das Letras, 2001.

. Assim falava Zaratustra. São Paulo: Companhia das Letras, 2011.

RAMOS, D. R. O Ereignis em Heidegger. Teresópolis: Daimon, 2015.

RILKE, R. M. Sonetos a Orfeu. Elegias a Duíno. Bragança Paulista: Universitária, 2005.

SARTRE, J.-P. O existencialismo é humanismo. In SARTRE, J.-P. O existencialismo é humanismo. $A$ imaginação. Questão de método. São Paulo: Abril Cultural, 1973. p. 10-38. (Coleção Os Pensadores)

Submetido: 10 de janeiro de 2021

Aceíto: 10 de fevereíro de 2021

Sobre abrir fendas, cravar o chão da existência: verdade e liberdade no pensamento tardio de Heidegger 